\title{
Bottom-Up Approach towards a Human Wellbeing Assessment for the Design of a Management Plan: A Study Case with Contributions to Improve Sustainable Management of Resources in a Northern Area of Mozambique
}

\author{
Rita Sofia Anastácioํㅜ, Lúcia Nunes Schertenleib ${ }^{1}$, Jorge Paiva², Jorge Ferrão, ${ }^{3,4}$, \\ Mário Jorge Pereira1, ${ }^{*}$ \\ ${ }^{1}$ Departamento de Biologia e CESAM, Universidade de Aveiro, Aveiro, Portugal \\ ${ }^{2}$ Faculdade de Ciências and Centre for Functional Ecology (CFE), Universidade de Coimbra, Coimbra, Portugal \\ ${ }^{3}$ Lúrio University, Nampula, Mozambique \\ ${ }^{4}$ Maluane-Cabo Delgado Conservation and Tourism, Pemba, Mozambique \\ ${ }^{5}$ AFPR-A For Plankton Research, Aveiro, Portugal \\ Email: ${ }^{*}$ mverde@ua.pt
}

Received 23 October 2014; revised 26 November 2014; accepted 5 December 2014

Copyright (C) 2014 by authors and Scientific Research Publishing Inc.

This work is licensed under the Creative Commons Attribution International License (CC BY).

http://creativecommons.org/licenses/by/4.0/

(c) (i) Open Access

\section{Abstract}

The loss of biodiversity and ecosystem services disturbance will result in serious ecological and socioeconomic consequences. How can people be prepared to be more efficient in preserving ecosystems, its services and resources? The Messalo Wilderness Area (MWA) is an area lacking a bottom-up approach for the design of a management plan. This research intended to develop a strategy to gather people's views to begin a human wellbeing assessment for the area, for which a Digital Questionnaire (DQ) was developed and tested. The specific objectives were to 1) verify the dispersion/distribution of people and elephants; 2) study the natural resources used by the inhabitants; 3) locate the areas from where the most important natural resources are extracted and where conflict between humans and animals occur; 4) propose a Management Plan (MP) capable of mitigating the human-animals conflict, promoting the conservation of elephants and, consequently, of other types of biodiversity, thus working towards a better socio-economical development of the area. The elements gathered in the consulted references were used to design several

\footnotetext{
"Corresponding author.
}

How to cite this paper: Anastácio, R.S., Schertenleib, L.N., Paiva, J., Ferrão, J. and Pereira, M.J. (2014) Bottom-Up Approach towards a Human Wellbeing Assessment for the Design of a Management Plan: A Study Case with Contributions to Improve Sustainable Management of Resources in a Northern Area of Mozambique. Open Journal of Ecology, 4, 1102-1127. http://dx.doi.org/10.4236/oje.2014.417090 
maps and cartographic figures shown in this article, using the Map Window software. These maps describe: fresh water distribution, habitat distribution, population dispersal and main road connections, crop fields distribution and main exploitation spots of the different resources, orography and topography. The results from the DQ analysis helped to gather indicators to the human wellbeing assessment. The information gathered in the literature and by inquiry was effective in confirming the high dependency of local people on land and sea resources, as well as the conflicts between people and wild animals, such as elephants and African wild dogs, and the reasons for those conflicts. The DQ is effective in gathering people's opinions and it constitutes an important tool in a bottom-up approach to the design of a management plan as to the design of the MP for the MWA.

\section{Keywords}

North of Mozambique, Ecosystem Services, Ecosystem Based-Management

\section{Introduction}

In the Millennium Ecosystem Assessment [1] it can be read that "economists typically seek to identify the various reasons why biodiversity and ecosystems are valuable to people", but facts show that most supporting, cultural and regulating services of nature are not valued because people are not aware that if services are not preserved they must be paid for [1]. These services are not directly observed or measured. Being aware of their importance and existence is not yet valued. Either directly or indirectly, ecosystems support one's own consumption, as well as the consumption of other species. Biodiversity is important for human wellbeing because it provides security, basic materials, health, good social relationships and most important of all, freedom of choice and action [2]. This is done directly because biodiversity is the core and basis of ecosystem services-Figure 1 [1]-[3].

Ecosystem goods (such as food) and services (such as waste assimilation) represent the benefits human populations derive from ecosystem functions. Ecosystem functions "refer variously to the habitat, biological or system properties or processes of ecosystems” [4]. This article, following Costanza et al. [4], chose also to refer to

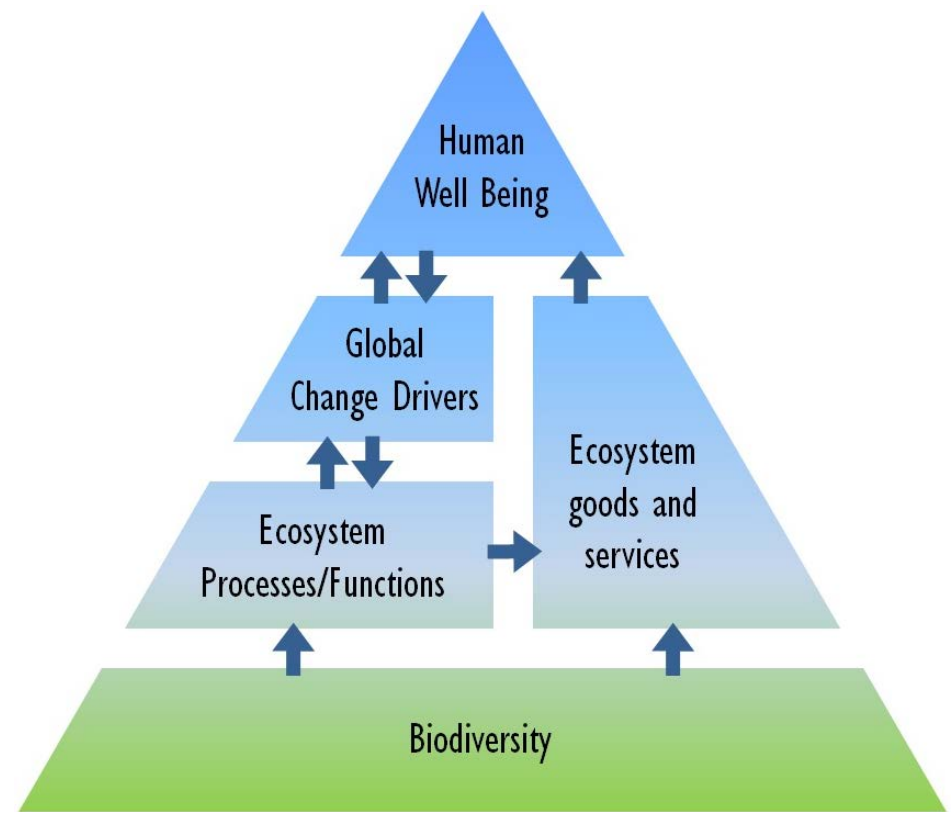

Figure 1. Interconnections among human wellbeing, global change drivers biodiversity, ecosystem processes, ecosystem services and biodiversity [1] [2]. 
ecosystem goods and services as Ecosystem Services (ES). The study they presented estimated the economic value of several ecosystem services. The calculus is important because it helps to be aware of ES value and the implications of certain governmental choices which interfere with nature services. People have to understand and believe that all actions will improve their quality of life [5]. Individuals "who rely most directly on ecosystem services, such as subsistence farmers, the rural poor and traditional societies, face the most serious and immediate risks from biodiversity loss" [2].

What would happen if people had to pay for most of the supporting, cultural and regulating services of nature? The value would be considerably high. The awareness of its value is still to come by means of education [1]. It's because these services are not directly observed, perceived nor measured that people still use them without knowing they have such value. The lack of awareness constitutes a problem for investigations that intend to enforce strategies to reduce pressure on ecosystems goods and services, with long-term results. Without the support of the ecosystems and their biodiversity, the consumption of basic natural materials is not possible, and the absence of those materials doesn't allow the accomplishment of the "human wellbeing" status, shown in the Figure 1 [1]-[3].

Planning and managing natural goods and services are recognized as being achievable and also a great challenge, because they involve investigators, stakeholders and communities in a long-term experience in which the consequences are unpredictable [6]. And because there are so many actors to listen, it is becoming increasingly important to develop strategies to gather their knowledge and views when it comes to making a wellbeing assessment.

Mozambique is a rich country in terms of natural resources. The Cabo Delgado Province is not different [7]. This paper focuses on the Messalo Wilderness Area (MWA), an area with 32.931 ha [8], on the evaluation of its natural resources and the means through which they are being explored by the inhabitants. Like other adjacent areas, MWA is being depleted of its natural capacity, due to overcrowding. The pressure on the land and seashore is observed in soil erosion, in wildlife habitat fragmentation, in the low productivity of the fields that are abandoned. The growing establishing of people in the MWA has been enabling several conflicts with wildlife. This scenario led to the need to understand what the local perceptions of the inhabitants towards wildlife (especially towards elephants) and ecosystem goods and services were. This perception is important for the design of a sustainable management plan of the natural resources. It's a bottom-up kind of approach, pursuing recommendations of Fraser et al. [6], since it intended to use the community knowledge of different villages to design the first step for a "wellbeing assessment".

This paper derives from a team work that was built to answer to a mission: contributing to the rural organization and management abilities of the natural resources of MWA. It also aims to contribute to the understanding of people's choices and needs, predicting and proposing changes which can improve sustainability locally, followed by an attempt to understand and evaluate local perceptions towards wild life and resources. This stage was centered in the Human-Wildlife Conflicts (HWC). It was intended to understand the position of people about a species of elephants: Loxodonta africana. Another wild animal was chosen, the carnivorous African Wild Dog (AWD), Lycaon pictus. Both species have the statutes "vulnerable” and "endangered", respectively, in the IUCN Red List of Threatened Animals (http://www.iucnredlist.org/apps/redlist/search).

The study also aims to produce a base plan with the contributions of the population, stakeholders and the available investigators, which can be refined by their continuous involvement in the creation and implementation of management committees. The organic structure of these committees is also proposed in this paper. The community and its stakeholders were engaged in the process by participating on the survey.

\section{Material and Methods}

Having this in mind, the first challenge was to collect information on people's livelihoods and their use of the available resources, as well as their perceptions towards wildlife in the MWA. The analysis of this information was critical to make decisions about strategies that would be suitable and/or accepted by inhabitants. This represents a small scale study, but it was organized in the following steps, based on Fraser et al. [6]: 1) organize and assess the people's knowledge; 2) choose some indicators from the people's knowledge; 3) collect the available indicators about the context; 4) combine and map indicators and indices; 5) propose a management plan.

For the first step the investigation team developed a Digital Questionnaire (DQ). Several investigators like Bradshaw and Bekoff [9] emphasize the importance of hearing and consider people's opinions to engage them 
with conservation measures. This is shared by a crescent opinion which defends that understanding and integrating social sciences with ecology is important to achieve success [10] [11]. The indicators we were trying to fulfil, in steps 2), 3), 4) were to: 1) verify dispersion/distribution of people and elephants; 2) make a recognition of the natural resources used by the inhabitants; 3 ) locate the areas from where the most important natural resources are being extracted and 4) where conflict between human-animal occurs.

This information led us to be able to combine and map the knowledge gathered for this area. It culminated with the proposition of a management plan to mitigate the Human-Elephant Conflict (HEC), and to promote the conservation of elephants, and, consequently, of other types of biodiversity that may sustain the human wellbeing in the MWA. It also led us to try to answer to the following questions exposed by Fraser et al. [5] in their paper: "Are people from MWA too poor to engage in a long-term management plan?”; "What are the major environmental issues in the MWA?”; "Do some groups depend on the environment for different resources?"

This plan was not yet been put into practice. But we believe this "bottom-up" and "close” approach can provide general awareness of how individual actions will result, in the future, in improvements in everyone's quality of life [5].

\subsection{The Area}

This study was carried out in the North of Mozambique in an area known as Messalo Wilderness Area (MWA) (Figure 2, Table 1), situated above the buffer zone of the QNP. It was initiated in April of 2009 and had the duration of two years, with field work done during 2010.

\subsection{Field Work Methodology}

\subsubsection{Maps and Cartographic Figures}

The cartographic figures shown in this and subsequent sections were generated in Map Window GIS 4.8.1. version, from the documental analysis of the existent charts, and from information collected through inquiry and observation during field work. Field-work information corresponds to coordinates measurement with a GPS device (Garmin model, Colorado 300), to the marking of the different habitats, to the signalizing of animal tracks,
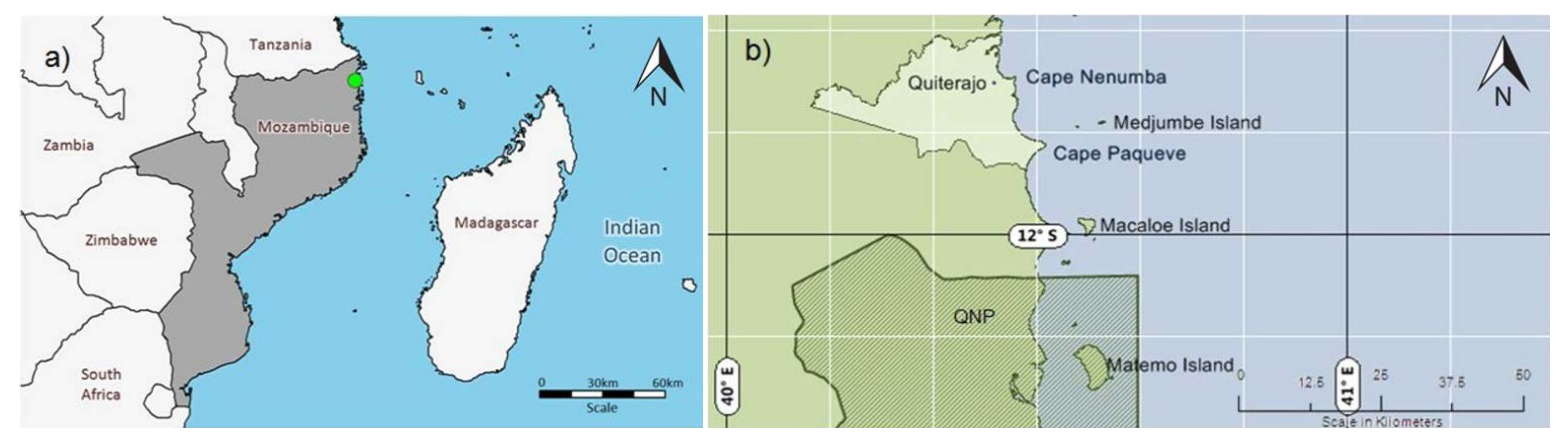

Figure 2. (a) The study area location (dot in Figure 2(a)) in Mozambique; (b) and the same area enhanced. Quirimbas National Parque (QNP), acording with: Decreto $n^{\circ}$ 14/2002 de 6 de Junho [12].

\begin{tabular}{|c|c|c|}
\hline \multirow{5}{*}{$\begin{array}{l}\text { Area } \\
\text { Limits }\end{array}$} & East limit & Indian Ocean \\
\hline & North limit & $\begin{array}{l}\text { Messalo river estuary } \\
\text { Lat } 11^{\circ} 40^{\prime} 17.83 \text { "S; Long } 40^{\circ} 26^{\prime} 16.02^{\prime \prime} \mathrm{E}\end{array}$ \\
\hline & Norwest and West limits & Mainstream of Messalo river \\
\hline & South limit & $\begin{array}{l}\text { Paqueve cape } \\
\text { Lat } 11^{\circ} 53^{\prime} 5.94 " S \text {; Long } 40^{\circ} 27^{\prime} 59.86^{\prime \prime E}\end{array}$ \\
\hline & South-West limit & $\begin{array}{l}\text { Part coincident with the Diquide river and part coincident } \\
\text { with the north line of the QNP buffer zone } \\
\text { Lat } 11^{\circ} 52^{\prime} 23.53^{\prime \prime} \text {; Long } 40^{\circ} 18^{\prime} 46.18^{\prime \prime E ~-~ L a t ~} 11^{\circ} 47^{\prime} 22.84 " S \text {; } \\
\text { Long } 40^{\circ} 8^{\prime} 10.26 \text { "E }\end{array}$ \\
\hline
\end{tabular}


signs and remains on field charts (sightings, kill sites, pellet/droppings), and to photographic and video records in several parts of the area.

Analysis of satellite images (from Google Earth) and of written documents from previous investigations in the area (see reports in reference section) were carried out.

The coordinates of the places, paths, villages and spots of interest were registered.

\subsubsection{Data Collection: Digital Questionnaires and Statistical Analysis and Definition}

To inquire the habitants using a computer, it was developed a digital questionnaire (DQ), as shown in Figure 3. This tool allowed for collecting and collate data according to human wellbeing categories (health and population, wealth, knowledge and culture, community, equity) and ecosystem wellbeing categories (land, water, air, species and genes, resources use) [6]. In detail, the DQ allowed for analysing the resources used, pressure on land and marine resources, positive and negative impacts of daily activities (e.g. forestry, agriculture, fishery, hunting, among others), the causes for human-animal conflicts (using the examples of African elephants and African wild dogs) and perceptions towards conservation actions. Missions, prior and during data collection, involved camping in Quiterajo and daily expeditions to the field and villages in the studied area. This provided an opportunity to inquire the population and stakeholders from different villages. During this stage, one community leader provided leadership, security and interpretation of the local dialects. Local guides and people also gave support and helped in the preparation of field logistics.

The sampling method was a mix of convenience sampling and purposive sampling (in the subtype's heterogeneity and snowball sampling) [13] [14]. Because the context is so particular (people are not used to being inquired and filling questionnaires), a type of convenience sampling was used and only volunteers were inquired.

The DQ was made in the Visual Basic Express Edition Software 2008. The collected data was stored in the Microsoft Access Database.

A pre-questionnaire was applied in January 2009 and the data was analyzed as a preview-test to identify bias in the procedure/questions. Then it was rectified and applied in the field again. The questions were asked faceto-face and the answers were typed in the DQ box by the interviewer. This way it was easier to make sure that every question was being answered. The process became very practical, fast, efficient and ecological.

Part of the collected data from the DQ was analyzed by a qualitative content methodology. Data was clustered in created categories, following Moreira's [13] and Bardin's [15] recommendations in the literature.

The sample was performed by 189 volunteers (2.3\% of the resident population) of which $6.5 \%$ were major stakeholders. Then data was analyzed using the following programmes: Microsoft Office Access 2007, Micro-

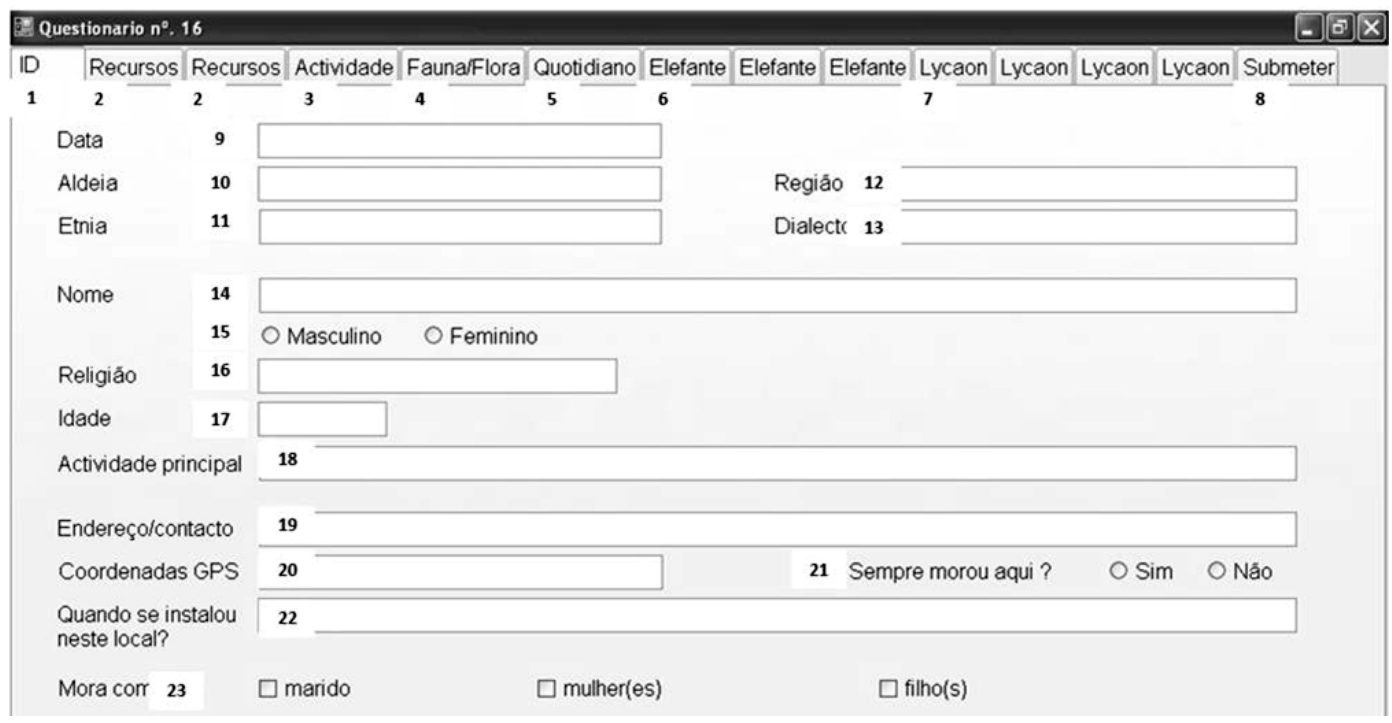

Figure 3. First window of the questionnaire. Numbers show the English translation of the section's titles: 1 . Identification of the subject; 2. Resources he/she uses/explores; 3. Daily activities; 4 . Wild fauna/flora explored/observed; 5. Relationships and community methods; 6 . Opinion about elephant and human-animal type of conflict; 7. Opinion about African wild dog and human-animal type of conflict. 
soft Office Excel 2007, PASW Statistics Data Editor 18, where variables were analyzed and categorized [14] [16]. The last two were used to perform descriptive statistical analysis and tests (nonparametric tests of Chisquare, Kruskal-Wallis H; and parametric tests of Oneway ANOVA and T-test).

The design of committees to develop and apply the plan mentioned in Section 4 was made from the field studies, from the results of the questionnaires and also from the analysis of other proposals.

\section{Results}

\subsection{Indicators Chosen from Literature}

\subsubsection{Coastal Aspects}

The MWA has approximately 32.931 ha [7], and it is located on the East coast of Africa in the North of Mozambique, Macomia district in Cabo Delgado Province (Figure 2, Table 1). Quiterajo is the village where the headquarters of the administration of the area is located (sede de posto administrativo). The area possesses several villages, each headed by one or two chiefs. Each village is also under the jurisdiction of the office of Quiterajo and is headed by its chief, who reports to the district administrator.

The coastal line has several coralliferous formations, sandy beaches and mangrove areas of which the most important one is the mangrove of Messalo river estuary. The inland shows several marine sedimentary rock formations [17]. It also shows variable elevations (under $135 \mathrm{~m}$ ) and presents an orography conditioned by various aquatic formations such as lakes (Kinhanquindu, Macungue), streamlets (Tubile, Chafi), rivers (Messalo, Muenha, Wadinhedi, Ngereda, Diquide) and also alluvion zones of the Messalo river, located in Buani and near the coast, between Paqueve (South) and Milamba (Centre) (Figure 4(a), Figure 4(b)).

Besides being influenced by the south equatorial current, the littoral (with thin continental platforms) is conditioned by the existence of three submarine canyons of East-West orientation (Kero Niuni in the North; Med-

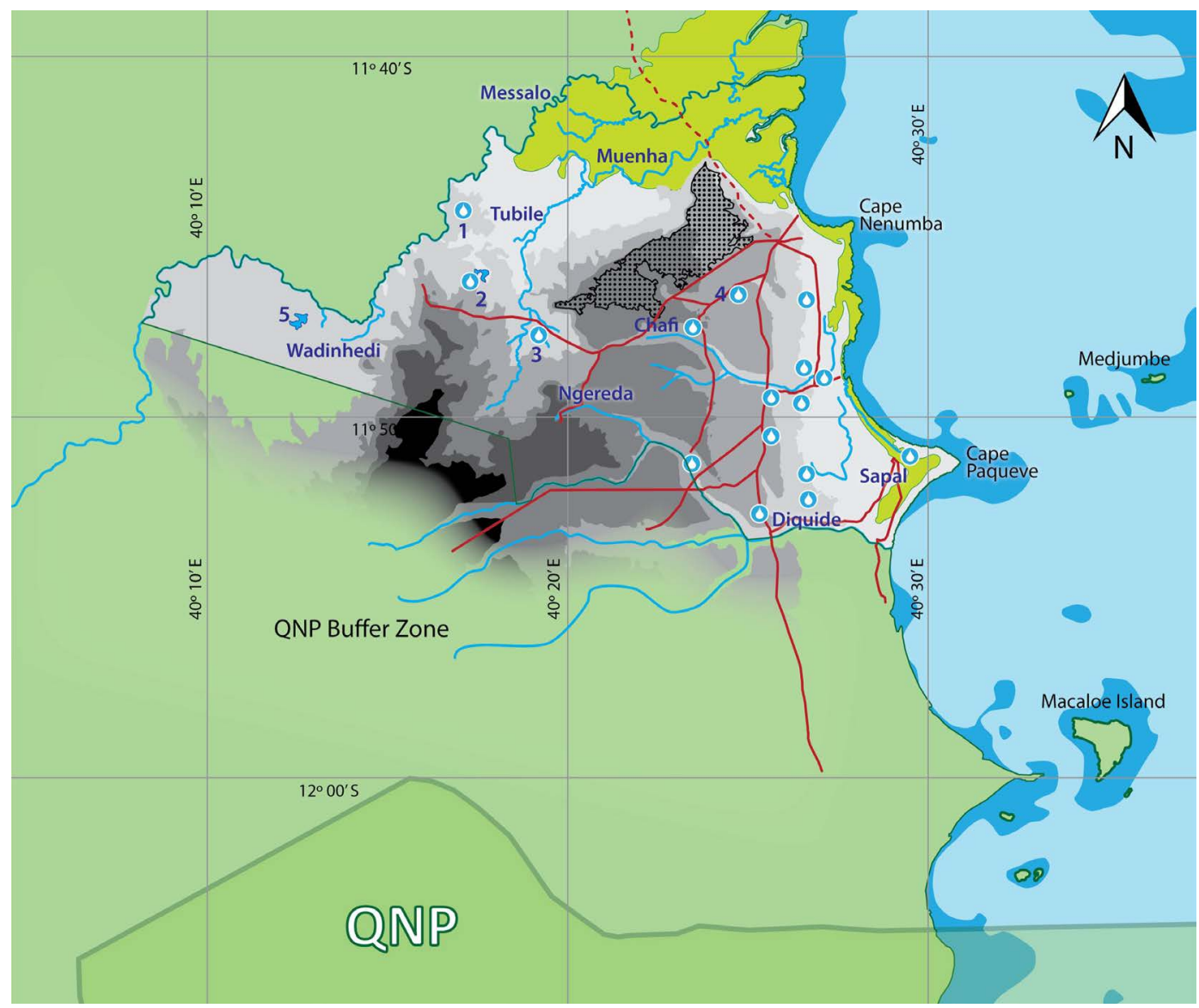

(a) 


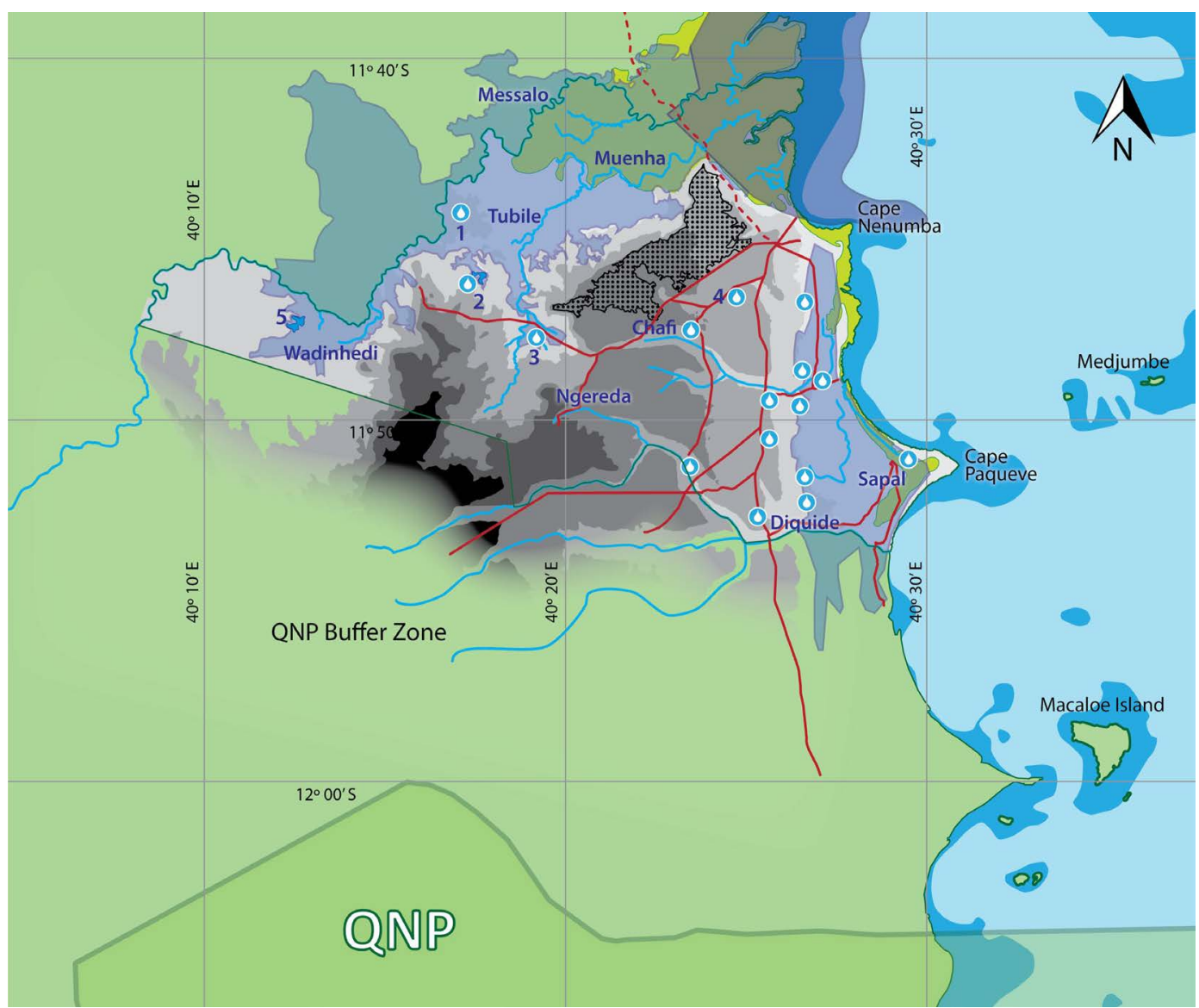

(b)

Figure 4. Main rivers (Messalo, Muenha, Tubile, Ngereda, Wadinhedi, Diquidi) in the dry season (a) and in the rainy season (b) showing the floodable areas. The numbered dots correspond to lagoons (1. Likuedo lagoon; 2. Macungue lagoon; 3. Buani lagoon; 4. Kinhanquindu lagoon). Figure prepared with information from: [18]; Google Earth, assessed in January 2010 and information obtained in the field by the authors.

jumbe in the Centre; Macaloé in the South) and also by barriers which constitute the islands and reefs of the Quirimbas Archipelago.

The littoral's turbidity, salinity and nutrient concentrations are influenced by Messalo, Muenha and Diquide rivers' discharges and by sediments brought by sliding waters resultant of intense rain. The Messalo river influence favors the existence of a large estuary and vigorous mangrove.

\subsubsection{Climate}

The area is influenced by the southern and northern monsoons, which create two seasons (winter/dry, summer/ rainy). The first monsoon affects the dry season and the second the rainy season. The climate is rainy and hot from October/January to April/May, summer period, and dry from June to September during the winter period. The summer monsoon influences the region with North-Northeast-East winds, which blow less than $5 \mathrm{~m} / \mathrm{s}$ in average, from September or November to February or March. The winter winds ( $9 \mathrm{~m} / \mathrm{s}$ in average) blow from south and southeast from March or May to September or October [19].

Earth and sea winds, connected to tide movements, influence the coast. The Mozambique current, which presents a flow of up to 4 knots and a tidal range of, in average, 0.7 - $4.6 \mathrm{~m}$ during spring tides and $2.1-3.0 \mathrm{~m}$ for neap tides [18], also influences this region. Sea water temperature varies between $20 / 25^{\circ} \mathrm{C}$ to $29 / 30^{\circ} \mathrm{C}$ [19], and usually presents higher values on the surface in low-tide periods. Sea surface temperatures can be inferior to $20^{\circ} \mathrm{C}\left(17-18^{\circ} \mathrm{C}\right)$. The air temperature average is about 18 to $32^{\circ} \mathrm{C}$ [17]. The annual precipitation is about 900 to $1000 \mathrm{~mm}$ (not much different from 1960), with values going from 800 to $1000 \mathrm{~mm}$ per year [17] [20]; and the 
relative humidity varies between $65 \%$ and $82 \%$ [21]. The index of aridity [22] goes from 20 to 30 [17], which indicates a climate type predominantly moderately arid.

\subsubsection{Ecosystems Diversity}

The area is located in the Eastern Miombo Woodland ecoregion [23], being occupied by the characteristic open forest of Brachystegia-Isoberlinia-Julbernardia (Brachystegia allenii, B. boehmii, B. spiciformis, Isoberlinia orientalis, Julbernardia globiflora) [24]-[26]. Alluvium areas can be found in Miombo, where some lagoons appear temporary (or relatively permanent), with the predominant herbaceous plants constituting pasture to herbivorous animals. These areas are extremely important, particularly in the dry season when herbaceous Miombo stratum dries. Between Miombo and the maritime border, a tropical grassland and a savanna develop, presenting small bushes and thick deciduous. Here, important biodiversity is also present such as Guibourtia schliebenii, climbing shrub or large liana (Strychnos spp.-S. spinosa, S. madagascariensis) and spine climbing shrubs like Guilandina bonduc.

Other habitats like floodplains, grasslands, lowland forests and a mountain forest plateau (the Quiujulo location) can be found and represent a refuge for several animals (Figure 5) [27]. They show several valuable plant species [28]. Mammals that have already been identified include elephants, buffaloes, various antelopes (waterbuck, eland, greater kudu, sable, suni, oribi, duiker), pigs and primates, elephant shrews and several large predators (spotted hyena, leopard, African wild dog and lion) [27] [29]. The terrestrial vertebrates, particularly mammals, have been included in a census to analyze their distribution and abundance. Monkeys (Papio cynocephalus, Cercopithecus pygerythrus), elephants (Loxodonta africana), suni (Neotragus moschatus) and waterbuck (Kobus ellipsiprymnus) and several species of reptiles and birds were identified by direct observation.

\subsubsection{Population Distribution and Numbers in the Literature}

This region has approximately 8164 inhabitants. Table 2 shows the distribution of individuals in the villages

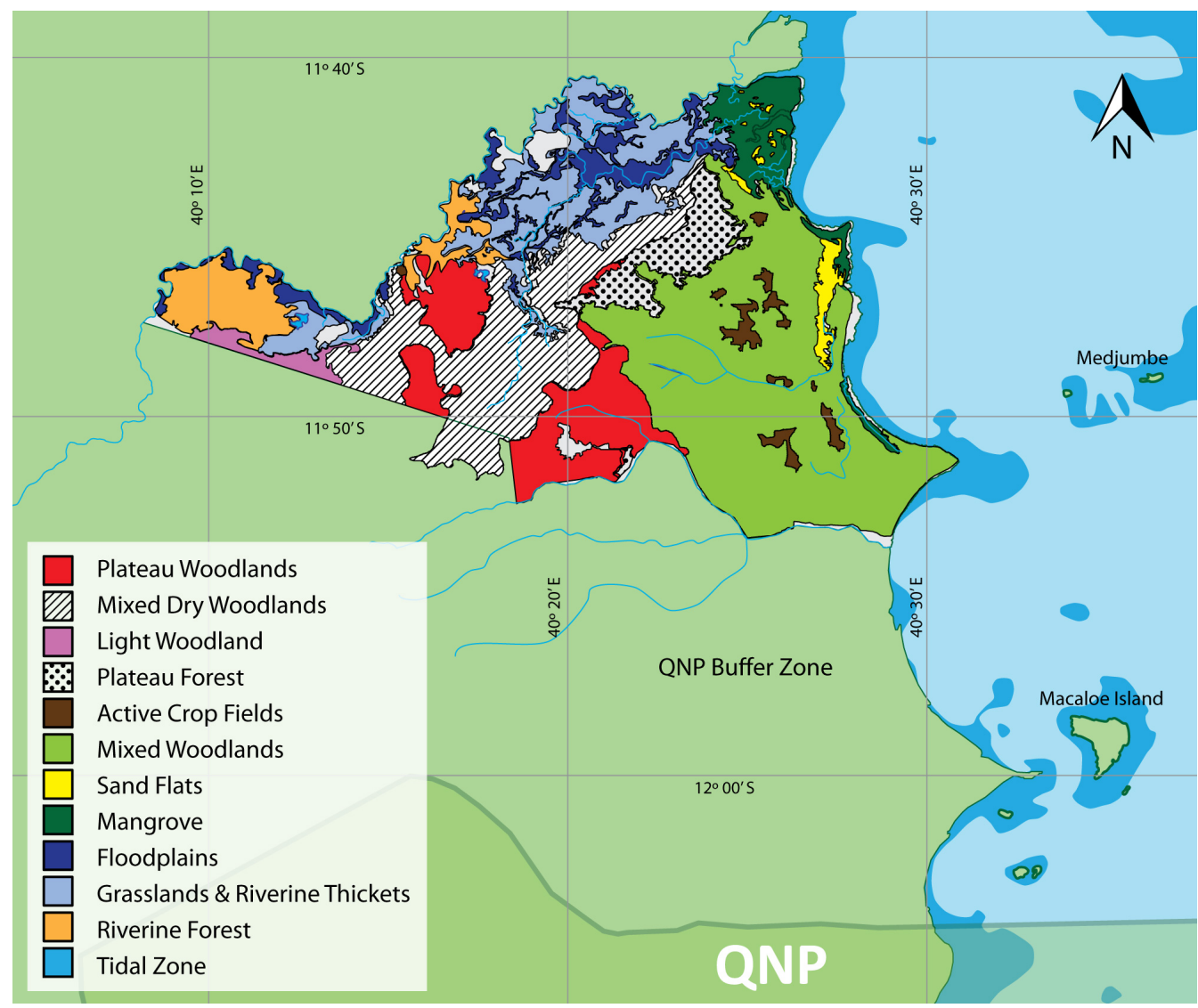

Figure 5. Distribution of habitats in the region (adapted from [27] and field observations by the authors). 
Table 2. Population, distribution per village and tendency: 2004/2006/2010.

\begin{tabular}{|c|c|c|c|c|c|c|}
\hline \multirow{2}{*}{ Village } & \multicolumn{3}{|c|}{ Population } & \multicolumn{3}{|c|}{ Variation } \\
\hline & $2004^{\mathrm{a}}$ & $2006^{\mathrm{b}}$ & 2010 & $2004-2006 \%$ & $2006-2010 \%$ & $2004-2010 \%$ \\
\hline Mitacata & 1391 & 1442 & 1472 & 3.7 & 2.1 & 5.8 \\
\hline Natugo I & 163 & 213 & 158 & 30.7 & -25.8 & -3.1 \\
\hline Natugo II & 474 & 576 & $* 576$ & 21.5 & - & - \\
\hline Paz & 113 & 130 & $* 130$ & 15.0 & 0.0 & 15.0 \\
\hline Unidade & 0 & 310 & 500 & 100.0 & 61.3 & 100.0 \\
\hline Malada & 252 & 257 & $* 257$ & 2.0 & - & - \\
\hline Milamba & 1796 & 1827 & 459 & 1.7 & -74.9 & -74.4 \\
\hline Namaneco & 597 & 697 & 250 & 16.8 & -64.1 & -58.1 \\
\hline Ilala & 1166 & 1366 & 1360 & 17.2 & -0.4 & 16.6 \\
\hline Mwera & & & 320 & - & - & - \\
\hline Paqueve & 1117 & 1426 & 2175 & 27.7 & 52.5 & 94.7 \\
\hline Likuedo & & 60 & $* 60$ & - & - & - \\
\hline Gaza & 352 & 0 & 125 & -100.0 & 100.0 & -64.5 \\
\hline Ibo & & 114 & $* 114$ & - & - & - \\
\hline 2000 & & 208 & *208 & - & - & - \\
\hline Total & 7421 & 8626 & 8164 & 16.0 & -5.3 & 10.0 \\
\hline
\end{tabular}

*Values of 2006; NA: note available; ${ }^{\mathrm{a}, \mathrm{b}}$ Data from Garnier, 2006 [30].

where the study was conducted. The data was first gathered in the Garnier report [30] and then updated using the information collected on the field. Unidade is a new village, and it was established as such in 2004. A negative variation means population loss by migration to other areas or surrounding villages. By analyzing the values of variation from 2004 to 2010 it is possible to conclude that some villages have suffered a decrease in their population: Natugo I, Milamba, Namaneco and Gaza. On the other hand others have been increasing its population: Unidade, Mwera.

The area has an approximate density population of 24.8 individuals per $\mathrm{Km}^{2}$. The majority of the population (93.8\%) lives along a corridor defined by the main road Mitacata-Ilala (no 247), and the coastal line MitacataPaqueve (15.766 ha). This corridor area has a population density of not less than 48.6 habitants per $\mathrm{Km}^{2}$ (Figure 6). As shown in Table 2, population is distributed over 15 villages. Ntumi et al. [31] refer to Cabo Delgado as a "less densely" populated province in which "elephants and other wildlife persist widely, especially close to protected areas such as the Niassa National Reserve, the Quirimbas National Park and the Zumbo region".

Immigration has become another important aspect, which interferes in the economy of the region and increases the exploitation of natural resources.

The official language is Portuguese. In the Quiterajo district only 13.5\% of the population in 1997 could speak Portuguese [32]. DSA [17] shows Mwani (spoken by the ethnic group Muani), Swahili (spoken by the ethnic group Suhaili), Makonde (spoken by the ethnic group Maconde), Makua-Medo and Makua-Makuana (both spoken by the Macuas) as language groups for this area.

\subsection{Indicators Shown by Inquired Perceptions (DQ Analysis)}

\subsubsection{Socioeconomic Indicators}

The interviewed $(N=189)$ are distributed by 13 of the 15 villages in the area according to the percentages: Gaza (1.1\%), Ilala (14.3\%), Malada (0.5\%), Milamba (13.2\%), Mitacata (23.8\%), Mwera (0.5\%), Namaneco (4.8\%), 


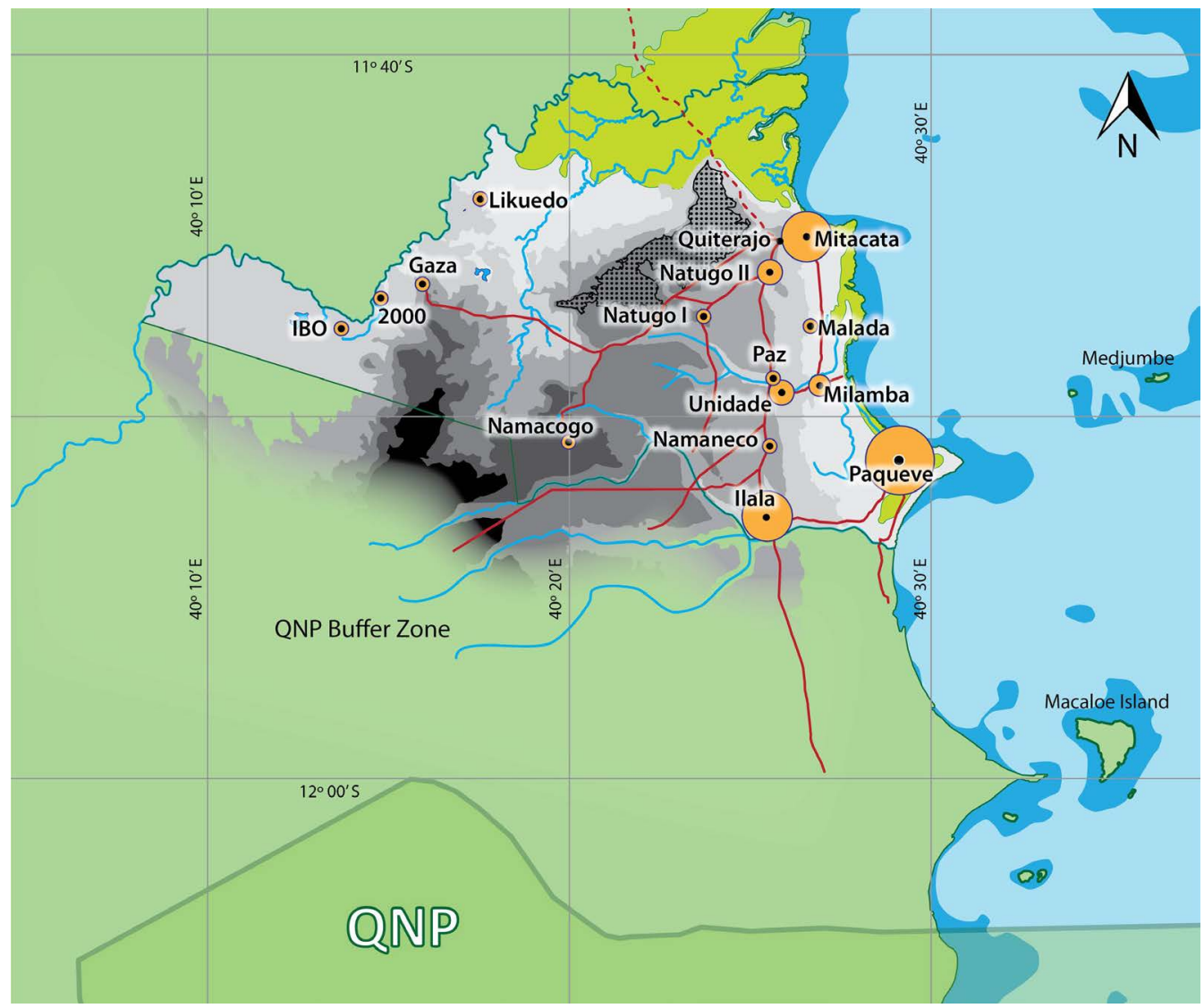

Figure 6. Main villages and main roads/pathways distribution through the area and population density/distribution (circles are proportional to density of population). Namacogo is an abandoned village.

Natugo I (6.3\%), Natugo II (9.0\%), Paz (3.7\%), Paqueve (12.1\%), Quiterajo (4.2\%), Unidade (6.3\%). The average age is $46.74 \pm 15.63$ years $(N=186)$. Figure 7 (a) shows a gender box plot of the inquired. Their ages range from 20 to 84 years old in both genders. Figure 7(b) shows a diagram of the education levels of the inquired individuals.

\subsubsection{Values and Beliefs}

The main religion is Muslim (94.7\%). A considerable percentage of the interviewed (46.6\%) have always lived in the area. From the total sample, $55.0 \%$ live with a spouse, and 50.8\% live with their children. The average of sons per household goes from 1 - 4 (depends on the village). The average of daughters per household ranges from 2 - 4. There are families with more than 10 children at their care.

The qualitative analysis of some answers to the open questions "who do you respect the most", "who has knowledge", "who takes important decisions", "who commands the reunions of the village council" revealed cultural aspects. These questions intended to define the stakeholders in whom people have confidence. Answers show that the traditional and political village leaders, the religious leaders and the elderly are recognized as the most respected people. They are also the knowledge keepers of the region culture and people. The interviewees mentioned the justice actors (such as judges) and traditional healers ("curandeiros") as being also important. Main decisions are taken in meetings with village leaders and councilors. These reunions take place in a central spot of the village (as a community house, or plaza), or in the political/traditional leader's house, or even in the moss. In these meetings stakeholders plan land distribution amongst other important decisions for the community.

\subsubsection{Economic Activities}

The majority of the interviewees practice traditional agriculture (62.4\%), without profit (39.2\%), meaning no income generation for the family (see Figure 8). The main economic activities of the region are linked to agri- 


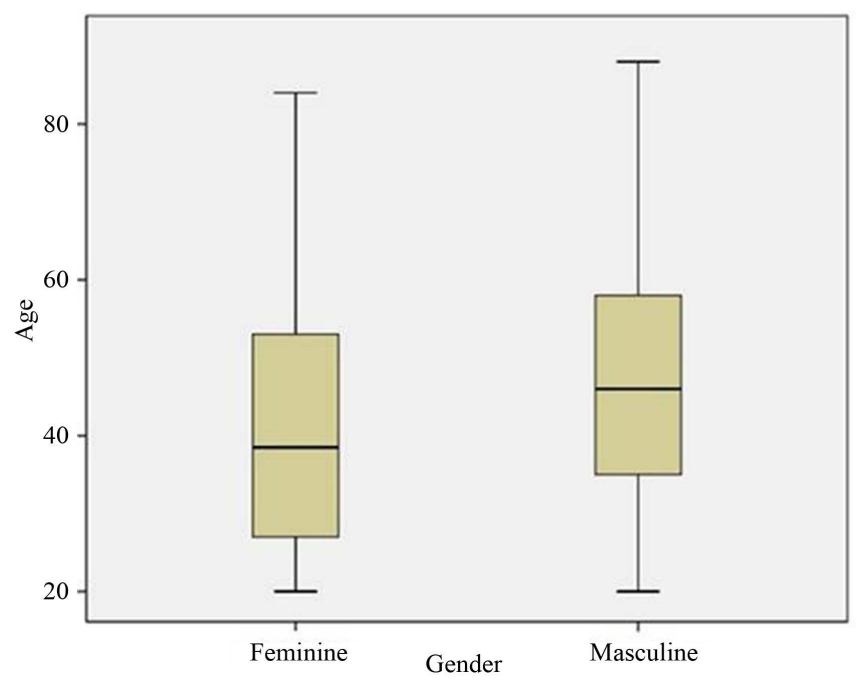

(a)

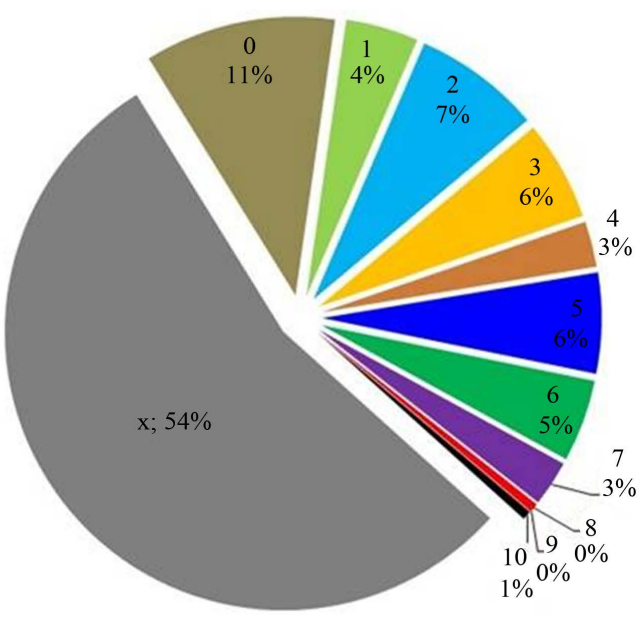

(b)

Figure 7. (a) Gender box plot from questionnaires results; (b) Pie Chart with percentages of the education levels from the inquired individuals; $\mathrm{x}$-don’t say his/her education level; 0—no education; 1-first class; 2-second class and so on.

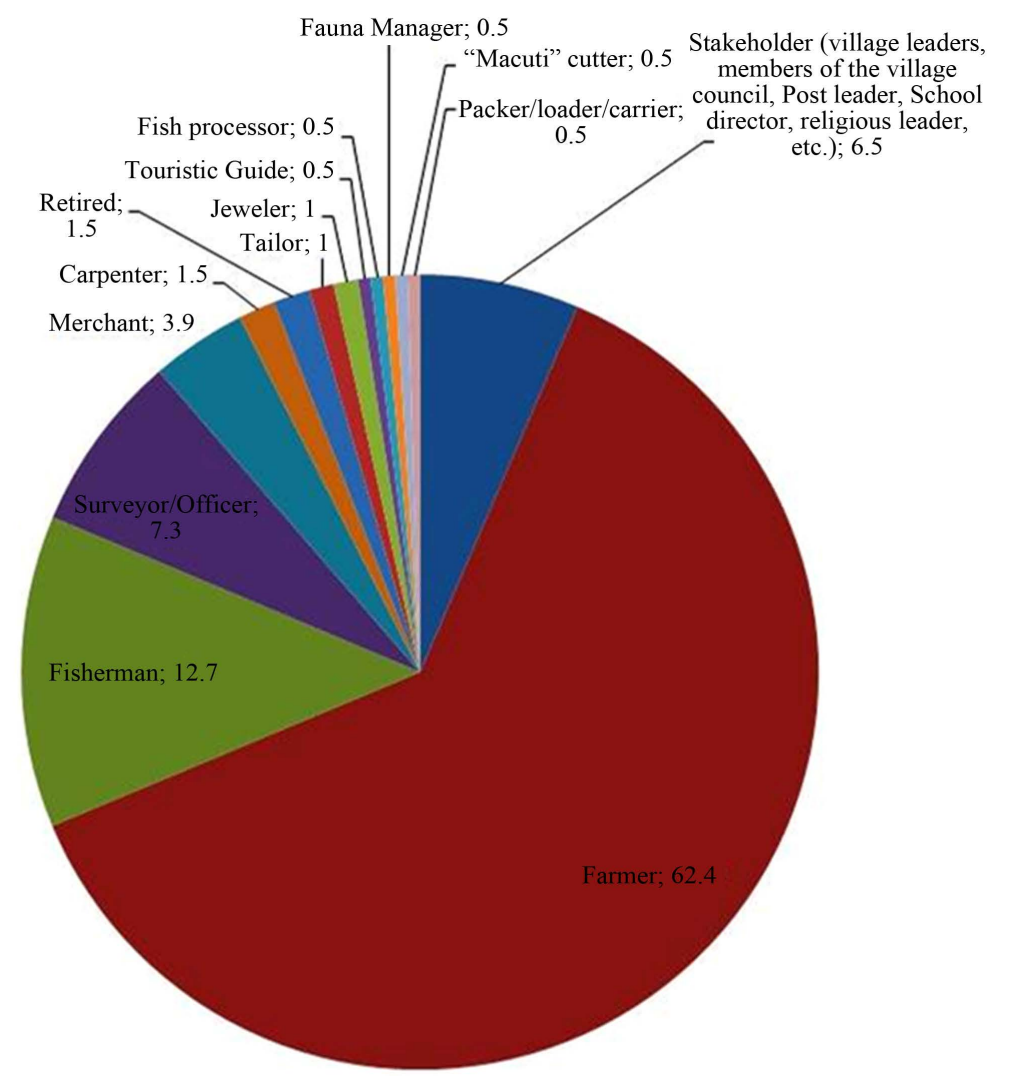

Figure 8. Professions/activities of the interviewees and the correspondent percentages.

culture. There is no use of machines in farming. This shows a precarious agrarian system.

Another traditional practice is fishery (34.9\%). For $12.7 \%$ of the interviewees it is the main profession. Only $18.5 \%$ of the individuals collect some profit of fishery. $10.6 \%$ use small boats, but there is no fishing fleet in the area or considerable port. 
Hunting is also an occupation. Only $2.1 \%$ admit to hunt wild animals and $94.0 \%$ of the interviewees admit to eating wild animals.

\subsubsection{Use of Natural Resources}

In Figure 9 it is possible to locate the spots from where the main resources are extracted.

Mitacata, Paqueve and Ilala are the villages with the biggest populations. This justifies the search and strong exploitation of resources in the periphery of these villages. Other villages are concentrated in the north-south axis near the coast. It is evident that the concentration of crop fields and resources spots in the surroundings of the same axis. Tables 3-5 gather the number of answers collected by inquiry, and respective percentages per village. These answers concern to resources exploitation. The goal was to make a list of the main natural resources explored in the area.

\subsubsection{Hydrologic Resources}

Fresh water is a very important resource (93\% of answers). Most of the interviewees (50.3\%) extract water from traditional wells with or without manual pumps (Figure 4(a), Figure 4(b)). Not only do people use water from these wells, but animals also drink from them. This similar need provides encounters. Water spots and paths are scarce and shared by animals and people. In the dry season some wells dry out. The drought obligates animals and people to search more frequently the same water spots. These shared places by the community and by wild animals can get very crowded. Most of the interviewees (>90\%) said to have other options not very far (less than $500 \mathrm{~m}$ from home). The water is used mostly to drink, cook, wash and bathe. Often, water from wells is of bad quality, frequently salinized and polluted.

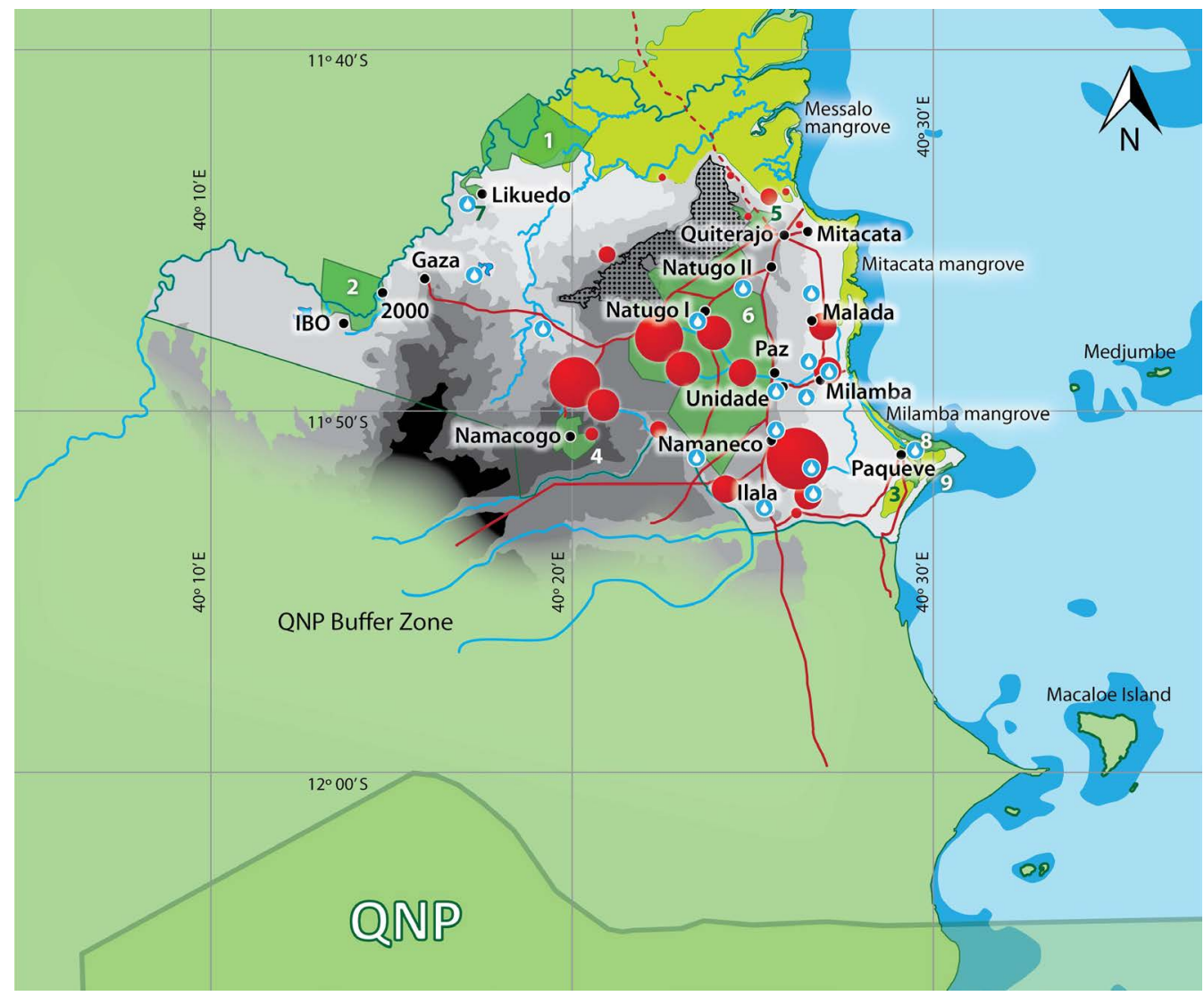

Figure 9. Areas of extraction of resources (numbers 1, 3, 7 are signalizing rice fields; 2, 4, 5, 6 are signalizing diverse crop fields (maize, cassava, sorghum, others); number 8 is signalizing the North Paqueve palm tree grove; number 9 is signalizing the South Paqueve palm tree grove). Circles (adapted from [29]) are proportional to the rate of extraction of the resources from the correspondent area. Dots (with rain drops) correspond to fresh water sources (traditional wells, lagoons). 
Table 3. Distribution of the energy/construction explored resources named in the sample; with number of cases and percentages per village and in total.

\begin{tabular}{|c|c|c|c|c|c|c|c|c|c|c|c|c|c|c|c|c|c|c|c|c|c|c|c|c|c|c|c|c|}
\hline \multirow{2}{*}{$\begin{array}{l}\text { Sample } \\
\text { Size }\end{array}$} & \multicolumn{2}{|c|}{$\begin{array}{c}\text { Anguane } \\
\& \text { \& } \\
\text { Paqueve }\end{array}$} & \multicolumn{2}{|c|}{ Gaza } & \multicolumn{2}{|c|}{ Ilala } & \multicolumn{2}{|c|}{ Malada } & \multicolumn{2}{|c|}{ Milamba } & \multicolumn{2}{|c|}{ Mitacata } & \multicolumn{2}{|c|}{ Muera } & \multicolumn{2}{|c|}{ Namaneco } & \multicolumn{2}{|c|}{$\begin{array}{c}\text { Natugo } \\
\text { I }\end{array}$} & \multicolumn{2}{|c|}{$\begin{array}{c}\text { Natugo } \\
\text { II }\end{array}$} & \multicolumn{2}{|c|}{ Paz } & \multicolumn{2}{|c|}{ Quiterajo } & \multicolumn{2}{|c|}{ Unidade } & \multicolumn{2}{|c|}{ Total } \\
\hline & 23 & 12.2 & 2 & 1.1 & 27 & 14.3 & 1 & 0.5 & 25 & 13.2 & 45 & 23.8 & 1 & 0.5 & 9 & 4.8 & 12 & 6.3 & 17 & 9.0 & 7 & 3.7 & 8 & 4.2 & 12 & 6.3 & 189 & 100 \\
\hline Petroleum & 20 & 10.6 & 0 & 0 & 24 & 12.7 & 1 & 0.5 & 20 & 10.6 & 39 & 20.6 & 1 & 0.5 & 6 & 3.2 & 9 & 4.8 & 8 & 4.2 & 7 & 3.7 & 6 & 3.2 & 9 & 4.8 & 150 & 79.4 \\
\hline Coal & 4 & 2.1 & 0 & 0 & 8 & 4.2 & 1 & 0.5 & 1 & 0.5 & 20 & 10.6 & 0 & 0 & 1 & 0.5 & 2 & 1.1 & 0 & 0 & 2 & 1.1 & 4 & 2.1 & 0 & 0 & 43 & 22.8 \\
\hline Rocks & 0 & 0 & 0 & 0 & 0 & 0 & 0 & 0 & 0 & 0 & 0 & 0 & 0 & 0 & 0 & 0 & 0 & 0 & 0 & 0 & 0 & 0 & 0 & 0 & 0 & 0 & 0 & 0 \\
\hline $\begin{array}{c}\text { Natural } \\
\text { Gas }\end{array}$ & 0 & 0 & 0 & 0 & 0 & 0 & 0 & 0 & 0 & 0 & 0 & 0 & 0 & 0 & 0 & 0 & 0 & 0 & 0 & 0 & 0 & 0 & 1 & 0.5 & 0 & 0 & 1 & 0.5 \\
\hline Minerals & 0 & 0 & 0 & 0 & 1 & 0.5 & 0 & 0 & 0 & 0 & 1 & 0.5 & 0 & 0 & 1 & 0.5 & 0 & 0 & 0 & 0 & 0 & 0 & 0 & 0 & 0 & 0 & 3 & 1.6 \\
\hline Sand & 23 & 12.2 & 2 & 1.1 & 25 & 13.2 & 1 & 0.5 & 25 & 13.2 & 45 & 23.8 & 1 & 0.5 & 9 & 4.8 & 12 & 6.3 & 16 & 8.5 & 7 & 3.7 & 6 & 3.2 & 12 & 6.3 & 184 & 97.4 \\
\hline
\end{tabular}

Table 4. Distribution of the green resources (forest resources, crop resources, etc.) named in the sample, with number of cases and percentages per village and in total.

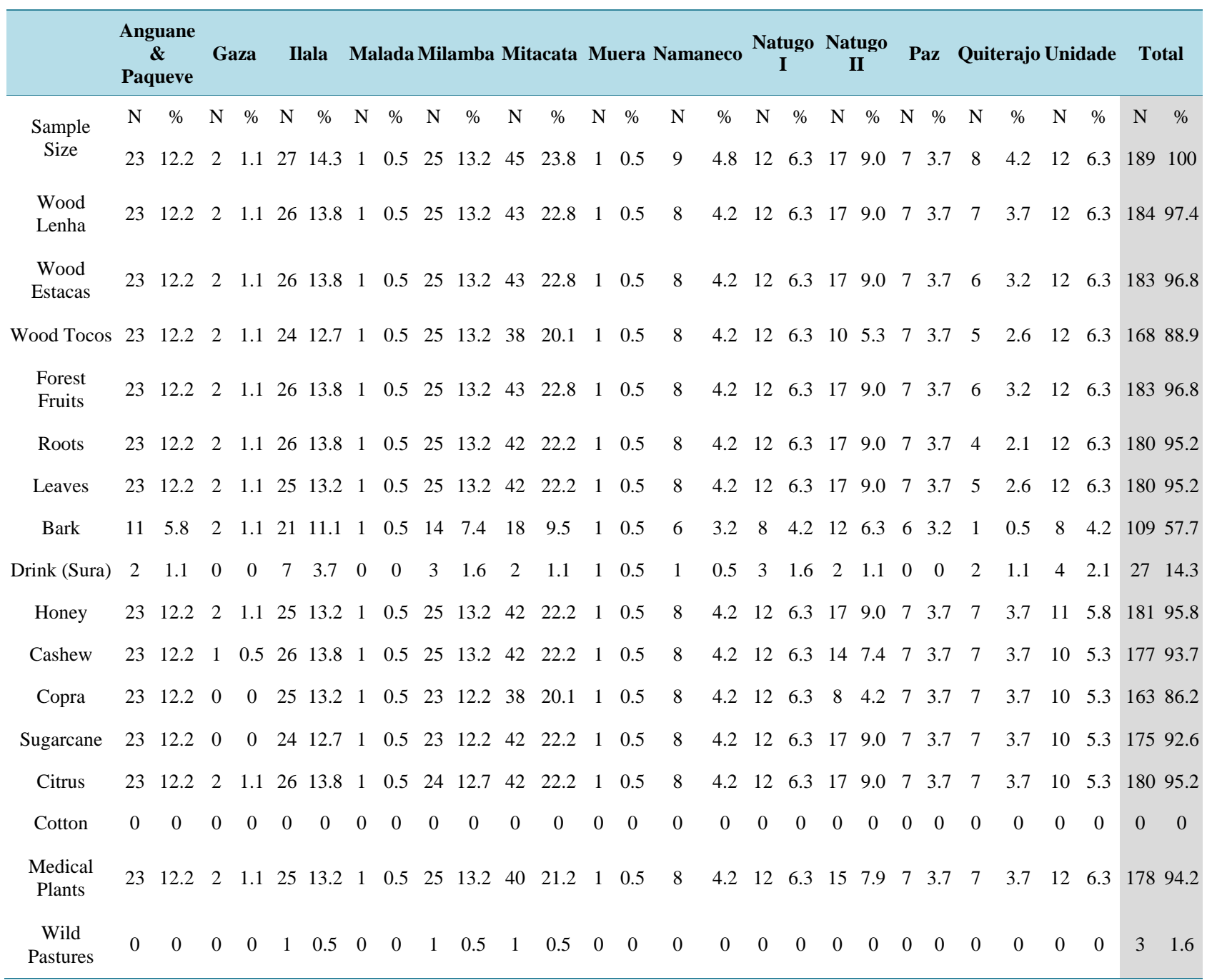


Table 5. Distribution of the livestock and wild animals explored named in the sample; with number of cases and percentages per village and in total.

\begin{tabular}{|c|c|c|c|c|c|c|c|c|c|c|c|c|c|c|c|c|c|c|c|c|c|c|c|c|c|c|c|}
\hline \multirow{3}{*}{$\begin{array}{l}\text { Sample } \\
\text { Size }\end{array}$} & \multicolumn{2}{|c|}{$\begin{array}{c}\text { Anguane } \\
\& \\
\text { Paqueve }\end{array}$} & \multicolumn{2}{|c|}{ Gaza } & \multicolumn{2}{|c|}{ Ilala } & \multicolumn{2}{|c|}{ Malada } & \multicolumn{2}{|c|}{ Milamba } & \multicolumn{2}{|c|}{ Mitacata } & \multicolumn{2}{|c|}{ Muera } & \multicolumn{2}{|c|}{ Namaneco } & \multicolumn{2}{|c|}{$\begin{array}{c}\text { Natugo } \\
\text { I }\end{array}$} & \multicolumn{2}{|c|}{$\begin{array}{c}\text { Natugo } \\
\text { II }\end{array}$} & \multicolumn{2}{|c|}{ Paz } & \multicolumn{2}{|c|}{ Quiterajo } & \multicolumn{2}{|c|}{ Unidade } & Total \\
\hline & $\mathrm{N}$ & $\%$ & $\mathrm{~N}$ & $\%$ & $\mathrm{~N}$ & $\%$ & $\mathrm{~N}$ & $\%$ & $\mathrm{~N}$ & $\%$ & $\mathrm{~N}$ & $\%$ & $\mathrm{~N}$ & $\%$ & $\mathrm{~N}$ & $\%$ & $\mathrm{~N}$ & $\%$ & $\mathrm{~N}$ & $\%$ & $\mathrm{~N}$ & $\%$ & $\mathrm{~N}$ & $\%$ & $\mathrm{~N}$ & $\%$ & $\mathrm{~N} \quad \%$ \\
\hline & 23 & 12.2 & 2 & 1.1 & 27 & 14.3 & 1 & 0.5 & 25 & 13.2 & 45 & 23.8 & 1 & 0.5 & 9 & 4.8 & 12 & 6.3 & 17 & 9.0 & 7 & 3.7 & 8 & 4.2 & 12 & 6.3 & 189100 \\
\hline Goats & 23 & 12.2 & 0 & 0 & 25 & 13.2 & 1 & 0.5 & 25 & 13.2 & 43 & 22.8 & 1 & 0.5 & 8 & 4.2 & 12 & 6.3 & 13 & 6.9 & 7 & 3.7 & 7 & 3.7 & 10 & 5.3 & 17592.6 \\
\hline Sheep & 23 & 12.2 & 0 & 0 & 25 & 13.2 & 1 & 0.5 & 23 & 12.2 & 39 & 30.6 & 1 & 0.5 & 8 & 4.2 & 12 & 6.3 & 13 & 6.9 & 7 & 3.7 & 6 & 3.2 & 10 & 5.3 & 16888.9 \\
\hline Pigs & 0 & 0 & 0 & 0 & 0 & 0 & 0 & 0 & 1 & 0.5 & 0 & 0 & 0 & 0 & 0 & 0 & 4 & 2.1 & 0 & 0 & 0 & 0 & 4 & 2.1 & 0 & 0 & $9 \quad 4.8$ \\
\hline Birds & 22 & 11.6 & 2 & 1.1 & 26 & 13.8 & 1 & 0.5 & 24 & 12.7 & 43 & 22.8 & 1 & 0.5 & 8 & 4.2 & 12 & 6.3 & 16 & 8.5 & 7 & 3.7 & 7 & 3.7 & 12 & 6.3 & 18195.8 \\
\hline $\begin{array}{l}\text { Savage/ } \\
\text { Wild } \\
\text { Animals }\end{array}$ & 23 & 12.2 & 1 & 0.5 & 25 & 13.2 & 1 & 0.5 & 25 & 13.2 & 42 & 22.2 & 1 & 0.5 & 8 & 4.2 & 12 & 6.3 & 16 & 8.5 & 7 & 3.7 & 6 & 3.2 & 11 & 5.8 & 17894.2 \\
\hline Fish & 23 & 12.2 & 2 & 1.1 & 26 & 13.8 & 1 & 0.5 & 25 & 13.2 & 43 & 22.8 & 1 & 0.5 & 8 & 4.2 & 12 & 6.3 & 17 & 9.0 & 7 & 3.7 & 7 & 3.7 & 12 & 6.3 & 18497.4 \\
\hline Crustaceous & 23 & 12.2 & 1 & 0.5 & 25 & 13.2 & 1 & 0.5 & 25 & 13.2 & 43 & 22.8 & 1 & 0.5 & 8 & 4.2 & 12 & 6.3 & 17 & 9.0 & 7 & 3.7 & 7 & 3.7 & 11 & 5.8 & 18195.8 \\
\hline Molusks & 23 & 12.2 & 0 & 0 & 26 & 13.8 & 1 & 0.5 & 24 & 12.7 & 43 & 22.8 & 1 & 0.5 & 8 & 4.2 & 12 & 6.3 & 17 & 9.0 & 7 & 3.7 & 7 & 3.7 & 11 & 5.8 & 18095.2 \\
\hline
\end{tabular}

\subsubsection{Mineral and Energy Resources}

The use of clay (89\%) and sand is very relevant (Table 3). It will be important to understand from where it is extracted. Petroleum and coal are expensive sources of energy to cook, for example. Not all individuals have access to these resources.

\subsubsection{Forestry}

The most important resources are wood, roots, leaves, wood bark, honey, cashew, copra, sugarcane and various herbaceous medicinal plants (Table 4). All types of wood are always named and in all villages. The majority seeks this resource in forests. The main purpose is to use them as an energy source. They also use them for construction of infrastructures (houses, for example). The interviewees also referred to macuti leaves (palm tree leaves of Hyphaene coriacea) (82\%) and bamboo (19\%) as materials used in construction.

Other results came from the qualitative analyses of the questions "What do you eat?", "What do you cultivate?”, “What products can’t you find in your village?”, “Do you trade your products?”, because some products are not named in the resources section, but then appear in the nutrition plan of the villagers. The main crops are beans, cassava (Manihot esculenta), maize, pumpkin, rice, watermelon. Less cultivated crops are sweet potato and cucumber. This type of vegetables integrates their meals. Other vegetables were referred; $10 \%$ refer having to search for products in other villages or locations. Copra and cashew cropping and wood exploitation in forestry are still observed nowadays.

\subsubsection{Livestock and Wild Animals}

Goats, sheep and birds (chickens) are the most used livestock (Table 5). Pigs are not important nor raised, because most of the individuals are Muslims. The number of people who refer to wild animals as a source of nutrition is high (94.0\%), but people don't mention where they get the meat.

Wild animals are seen very often. Turtles, snakes ("mamba” with $14.8 \%$ answers), and crocodiles (63.5\%) are the most seen reptiles. The most important seen birds are bush chickens ("Nambiri", "Ololo", "Anga" are common names for bush chickens). The Figures 10(a)-(c) show graphs and correspondent list (see Table 6) of mammals seen in the area. Several antelopes (grouped and identified by the letter (A), monkeys and baboons (B), elephants (C), bush pigs (D), leopards (E), lions (F) and buffalos (G)) are the most seen and reported mammals. Several can be seen in the Quiujulo location, which is situated in the Muenha river basin. This area is very particular as it is almost untouched by human actions (see Figure 5, the Plateau Forest location). 

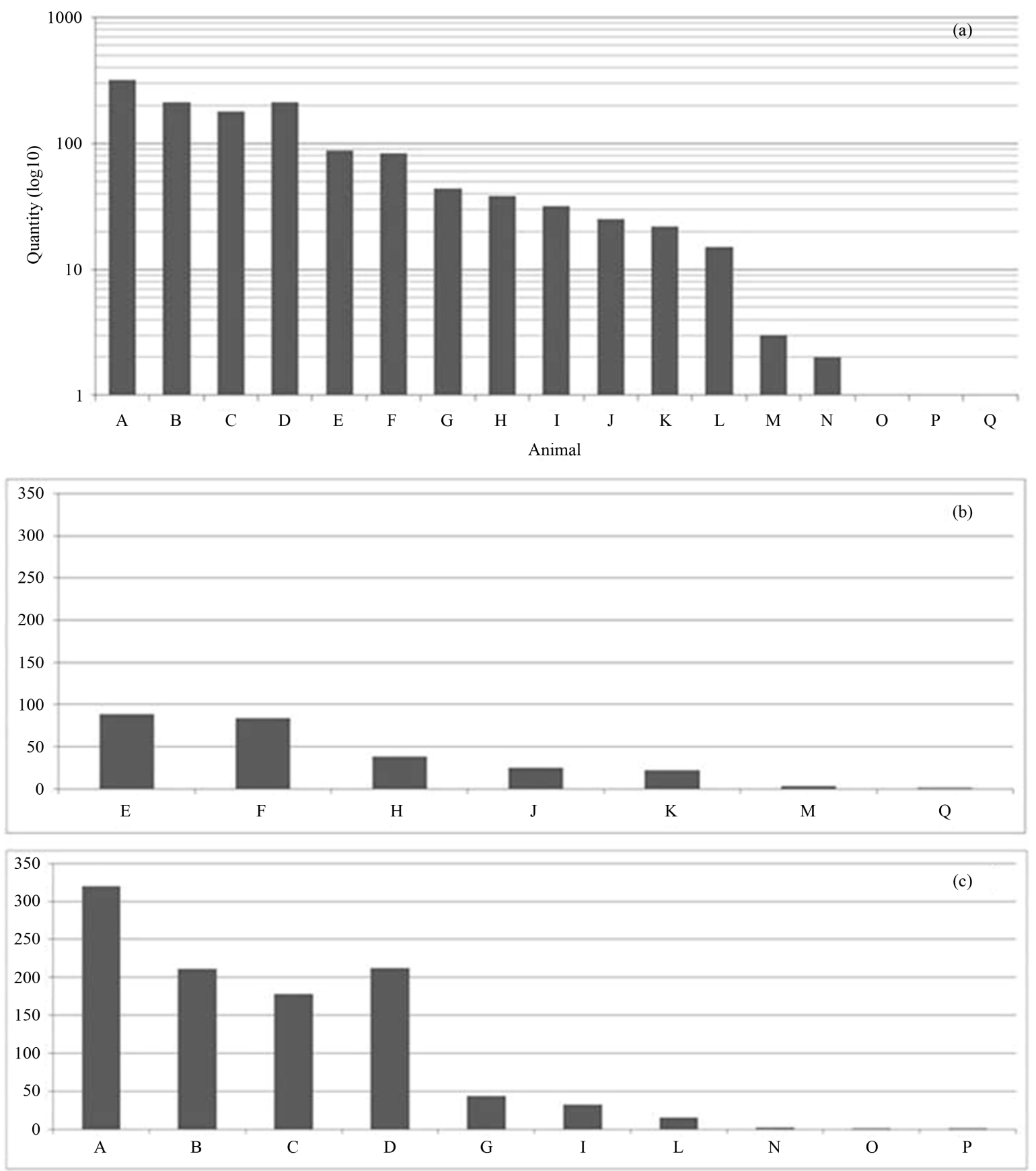

Figure 10. (a) Graph showing the main mammals seen by the interviewees in the region. For knowing the meaning of the letters see Table 5; (b) Graph showing carnivorous seen in the region; (c) Graph showing herbivorous and other mammals seen in the region. Letters' meanings are the same shown in (a). Y-axis shows the number of answers for each animal.

\subsubsection{Marine Resources}

Fish, crustaceous and marine mollusks are part of the diet. Coral reefs have been suffering destructive actions due to activities and arts related to fish and mollusks catch. The population also transforms corals into lime, using this product in construction. Trophic chains linked to coral environments are diverse. However, human practices have been compromising intermediate levels in this trophic connectivity. The catch of fish larvae, juveniles of several species and of adult specimens for human consumption and commercialization is a practice in the MWA. The intensive capture of crustaceans like crabs, lobsters, prawns and shrimps has been frequent as well. 
Table 6. Table with the identification of the animals seen by the villagers.

\begin{tabular}{|c|c|c|c|}
\hline Animal & Comon name (English) & Comon name in Mwani & Species \\
\hline A & Great Kudu & Nandolo & Tragelaphus strepsiceros \\
\hline A & Impala & ? & Aepyceros melampus \\
\hline A & Nyala & Inhala & Tragelaphus angasii \\
\hline A & Waterbuck & $\begin{array}{c}\text { Nandoro (Kimwani) }=\text { Nandolo (Makonde language) } \\
=\text { Inhacoso = Piva }\end{array}$ & Kobus ellipsiprymnus \\
\hline $\mathbf{A}$ & Suni & Nazolo & Neotragus moschatus \\
\hline A & Sable & Palavi (Makua language) & Hippotragus niger \\
\hline A & BushBuck & Mbawalla = imbabala & Tragelaphus scriptus \\
\hline B & Baboon & Nyani & Papio cynocephalus \\
\hline B & Samango & Ima & Cercopithecus albogularis \\
\hline B & Vervet & Nhumbire & Cercopithecus pygerythrus \\
\hline C & Elephant & Nembo & Loxodonta africana \\
\hline D & Warthog & Mango & Phacochoerus africanus \\
\hline $\mathbf{E}$ & Leopard & (Suhui) Suwi & Panthera pardus \\
\hline $\mathbf{F}$ & Lion & Simba & Panthera leo \\
\hline G & Buffalo & (Inhati) Nyati & Syncerus caffer \\
\hline \multirow[t]{2}{*}{$\mathbf{H}$} & Spotted Hyaena & Fisi & Crocuta crocuta \\
\hline & Bush Duiker & Nanjanga & Sylvicapra grimmia \\
\hline \multirow[t]{2}{*}{$\mathbf{I}$} & Red Duiker & Kutuku (Makua language) & Cephalophus natalensis \\
\hline & Oribi & ? & Ourebia ourebi \\
\hline $\mathbf{J}$ & ? & Raposa (?) & ? \\
\hline $\mathbf{K}$ & African Wild Dog & Mwizi & Lycaon pictus \\
\hline $\mathbf{L}$ & Hippo & Chiboko (Maconde language), Namonto & Hippopotamus amphibius \\
\hline $\mathbf{M}$ & Side-striped Jackal & Nancheto & Canis adustus \\
\hline $\mathbf{N}$ & Porcupine & Nachinugo & Hystrix africaeaustralis \\
\hline $\mathbf{O}$ & Aard-vark & Nanyoma & Orycteropus afer \\
\hline $\mathbf{P}$ & Wildebeest & ? & Connochaetes taurinus \\
\hline $\mathbf{Q}$ & Wild cat & Maka nundu & Felis lybica \\
\hline
\end{tabular}

Cartilaginous and bony fishes from the families Dasyatidae, Carangidae, Hemiramphidae, Lutjanidae, Scaridae and, with less frequency, Serranidae have been also intensively captured.

Turtles such as “Assa” (Green, Chelonia mydas), "Nhamba” (Hawksbill, Eretmochelys imbricata) and "Liluvi” (Loggerhead, Caretta caretta)—names in Kimwani dialect—are also present (69.3\%).

\subsubsection{Local Perception of the Importance of Biodiversity}

\section{1) Human Wildlife Conflict with African Wild Dog}

One problem concerning the African wild dog has been pointed out. Their occasional attacks on livestock preoccupy the population. However, the African wild dog shares this guilt with other carnivorous (lions, leopards) and are less feared. Monkeys are also pointed out as animals that attack people and resources. In contrast, 
Lycaon pictus are not as hated as elephants, because they also present some advantages to the interviewees. People referred that when African wild dogs are present other dangerous carnivorous are kept away. African wild dogs eat some resources (livestock) but don't destroy crop areas like elephants do when they invade crop fields. So African wild dogs are seen as useful and other predators and elephants are not. This doesn't mean people accept their near presence. People would prefer all type of wild animals to be in a different area, specially because they don't like to share natural resources, as they admitted. So the major solution advanced by the inquired was physical separation between African wild dogs and people.

\section{2) Human Elephant Conflict (HEC)}

Conflicts in the Quiterajo-Ilala area occur, mostly, between January and June. Garnier [30] refers, for the period between 2003 and 2006 that 94\% of elephant crop raiding occurred during the first semester.

When it was asked "what do you think of the presence of elephants", 33.3\% of the interviewed weren't favourable about their presence (only one favourable answer). These animals are considered a problem and are non desirable. It was understood why the interviewed have this perception: 51.9\% of them said they had problems caused by elephants. Mostly related with consumption of water and crop products (22.2\%), followed by the invasion and destruction of crops and goods (14.8\%). Also attacks to people are mentioned (3.7\%). However, when it was asked what they thought of total disappearance of elephants from the area, though $37 \%$ give any answer, 33.3\% said it would be bad, against $29.6 \%$ saying it would be good. Their reasons are stated in Table 7 .

The interviewed are receptive to support measures to diminish the conflict with the elephants $(59.3 \%$ in favour vs. $40.7 \%$ missing). The presence of elephants creates insecurity among residents of MWA. However, the answers clarify that communities don't want to share space or resources with these animals: $18.5 \%$ saying there is "no possible solution of sharing space", $66.7 \%$ saying animals should be in a fenced area, apart from the people, $7.4 \%$ saying culling would be the solution, and 3.7\% saying they don't have ideas for solutions (and 3.7\% missing answers). This shows that $92.6 \%$ of the inquired think that the solution of the conflict is non-coexistence. People want physical separation from wild animals. There is only one opinion/suggestion of co-existence and space sharing, which implies the construction of community crop fields with surveillance.

Another relevant aspect is that the need for resources overcomes the fear of wild animals. This is the reason why populations occupy some of the passages previously used by elephants (Figure 11).

In this scenario, perceptions towards wild animals are shared between the ones that were victims and the ones that weren't victims. This was concluded after the application of a Pearson Chi-square test to a subsample, derived from the division of our sample in three: sample "corridor villages" (most affected by elephant attacks); sample "coast villages"; and sample "interior villages" (less attacked). The results showed to be not statistically significant, in what concerns to the opinion of these three groups (the Pearson Chi-square $=3.160 ; \mathrm{P}=0.206 ; N$ = 137) for the question "Do you think it would be good if elephants disappeared?"

\section{Discussion}

\subsection{Human Well Being Issues in the Area}

The analysis of the results showed that the major environmental issues resident communities face are: conflicts with wild animals, mainly elephants, low productivity of crops and fisheries and deficient water supply, low income, insufficient access to energy sources and low education levels. Problems also emphasized by Ntumi et al. [31] in their work on Mozambique. Because of these indicators, the human well-being is not easily achievable, given that people are poor and vulnerable. Also, exploring natural resources is a problem, as maintaining these resources are increasingly challenging and difficult. The same problems are highlighted by Mabunda [33], Rosendo et al. [34] for adjacent regions.

One reason why local communities and corresponding crops are vulnerable to wild animals, such as elephants, is highlighted by the topographic analysis of the region revealed by Figure 11. In certain areas a natural passageway (a corridor) gives direct access to the coast where food and water can be found in the dry and rainy seasons. The area covered by elephants is larger than what is visible in Figure 11. The corridor passes in the middle of the largest crop area that belongs to Paz, Unidade, Milamba, Namaneco and Ilala villages and overlaps, to a large extent, the area where Garnier (2006) reported crop damage (54\%) and other incidents (76\%) [30]. Some of the villages were created near this corridor or moved closer to it. The Unidade population, for example, was set after 2004 by the former inhabitants of Namacogo, and has been showing a considerable population growth since then. 
Table 7. Positive and negative views/ideas stated in questionnaires by the interviewed about the presence of elephants in the area (qualitative analysis of the answers).

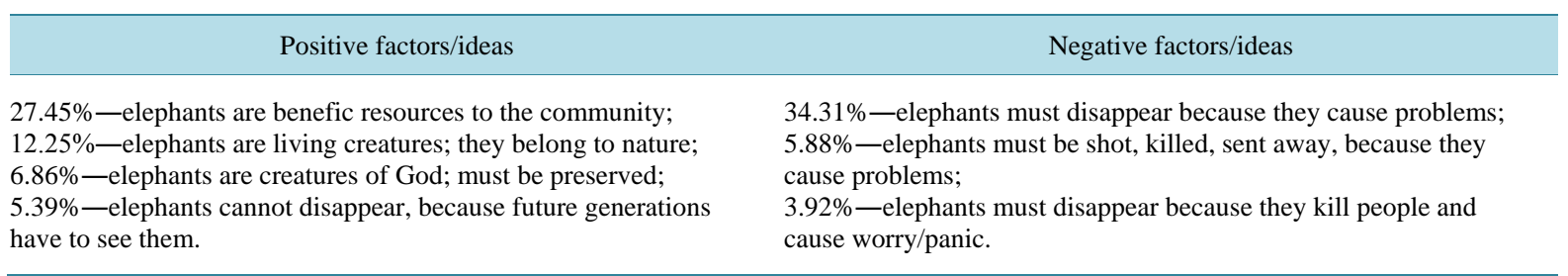

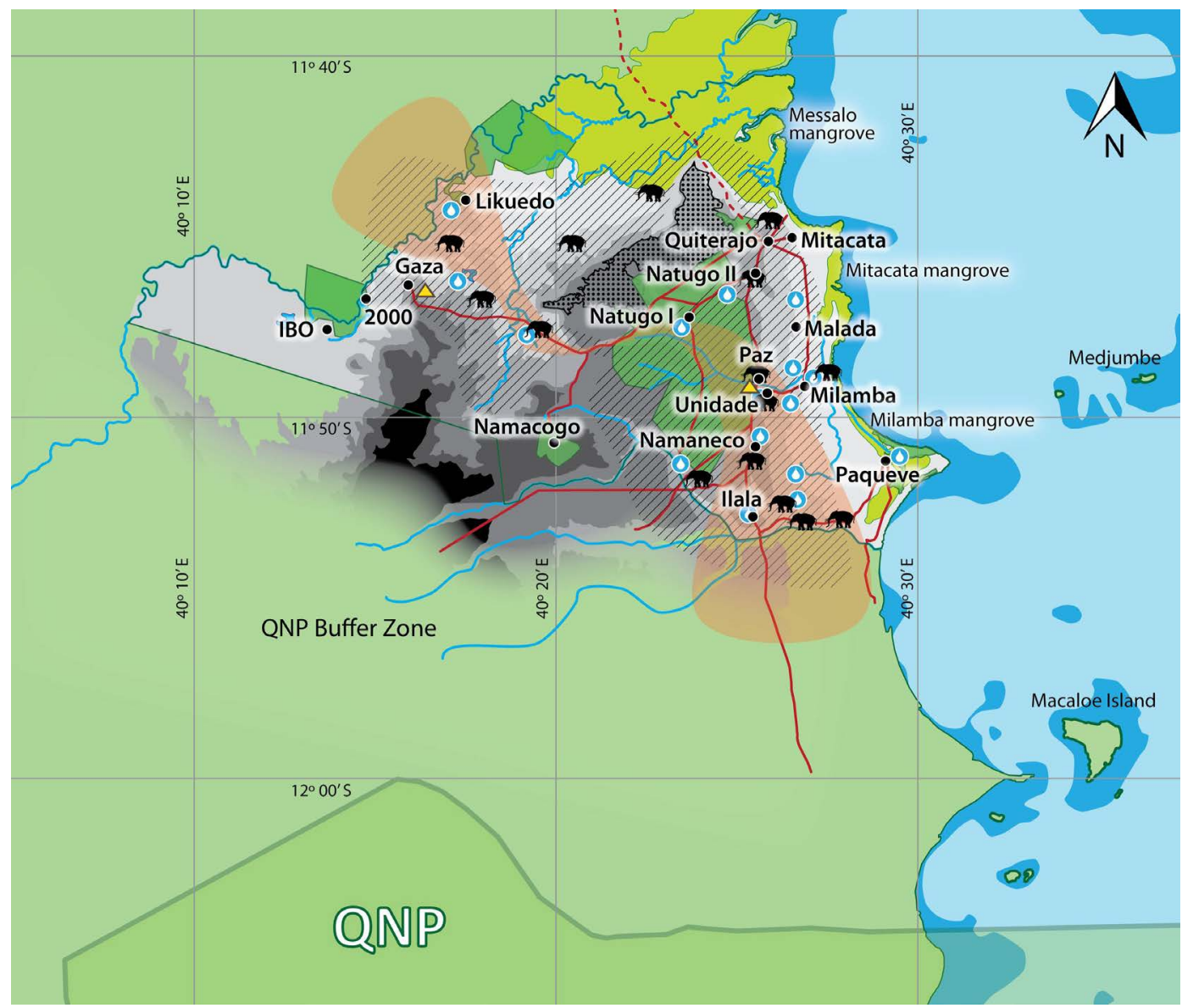

Figure 11. Area of distribution and occurrence of elephants (dashed area). Triangles indicate African wild dogs occurrences. The delimited area at the center of the Figure 11 indicates the possible corridor used by animals to Quirimbas National Park (QNP). In grey are altimetry levels (0 (white)-20-60-100-140-180-200 (black) meters). Polygonal areas are crop fields of the villages.

Freshwater spots and paths are shared by animals and people, specially in the dry season. The drought obligates animals and people to search more frequently the same water spots. This is one of the reasons why respondents argue for physical separation between them and wild animals. The great pressure is mainly in the coastal area, concerning the villages of Natugo I, Paz, Unidade, Namaneco and Ilala. The freshwater points are also concentrated near these villages.

In the MWA, like in other locations of MZ and Africa, the problem with wildlife is related with land use. This is the grand reason for the existence of human-elephant conflicts as emphasized by Hoare [35], who defends that "in any country the solution must involve people at many different administrative levels". This is possible in MZ with a Vertical Integration Model (VIM), since the African Elephant Specialist Group (AfESG) evaluation of the application of a VIM in Mozambique and Tanzania was favourable [35] due to other actions on the field. 


\subsection{The Management Plan}

There was a major concern to design a plan capable of minimizing the HEC pointed out by the interviewed, and of protecting wild life forms. The MWA was visualized and subdivided in: protected areas, corridor and conditioned-use areas. Figure 12 shows the distribution of villages, existent crop fields to maintain, crop fields to propose (areas A, B, C and D), main rivers, mangroves, resource exploitation sites (dots), and non-use areas. The non-use areas are coloured for the land (Land Protected Areas, LPA) and for the sea (Marine Protected Area, MPA). The MPA is proposed for the Paqueve Cape area and the Messalo estuary and it contains different ecosystems, like mangroves at the north, and important geological features (see Figure 5). The objective of this MPA is to protect the mangroves of Mitacata, Malada and Milamba.

The corridor is marked in grey color in Figure 12. It is essential to allow passage for elephants and other wild animals to areas with fresh water and food near the shore. To minimize the HEC a fence-strategy is proposed (dashed lines, Figure 12) to protect some villages (Unidade, Paz, Milamba, Ilala) and crop fields (D section, specially).

Douglas-Hamilton et al. [36] emphasize that elephants have home sectors linked by travel corridors. In their study they say that "the areas required by elephants are so large" that it would be inconsistent to confine them solely to protected areas. They seem to have the need for moving from one area to another. That is why DouglasHamilton et al. [36] propose an investment in keeping open crucial corridors. The MWA seems to have an important corridor used by elephants, which is possibly used for a long time. Information gathered inclines us to suppose that this corridor gives access to the coast, and also provides food and water in the dry season. This wildlife natural corridor also allows passage between terrain elevations (like the Quiujulo formation). Wall et al.

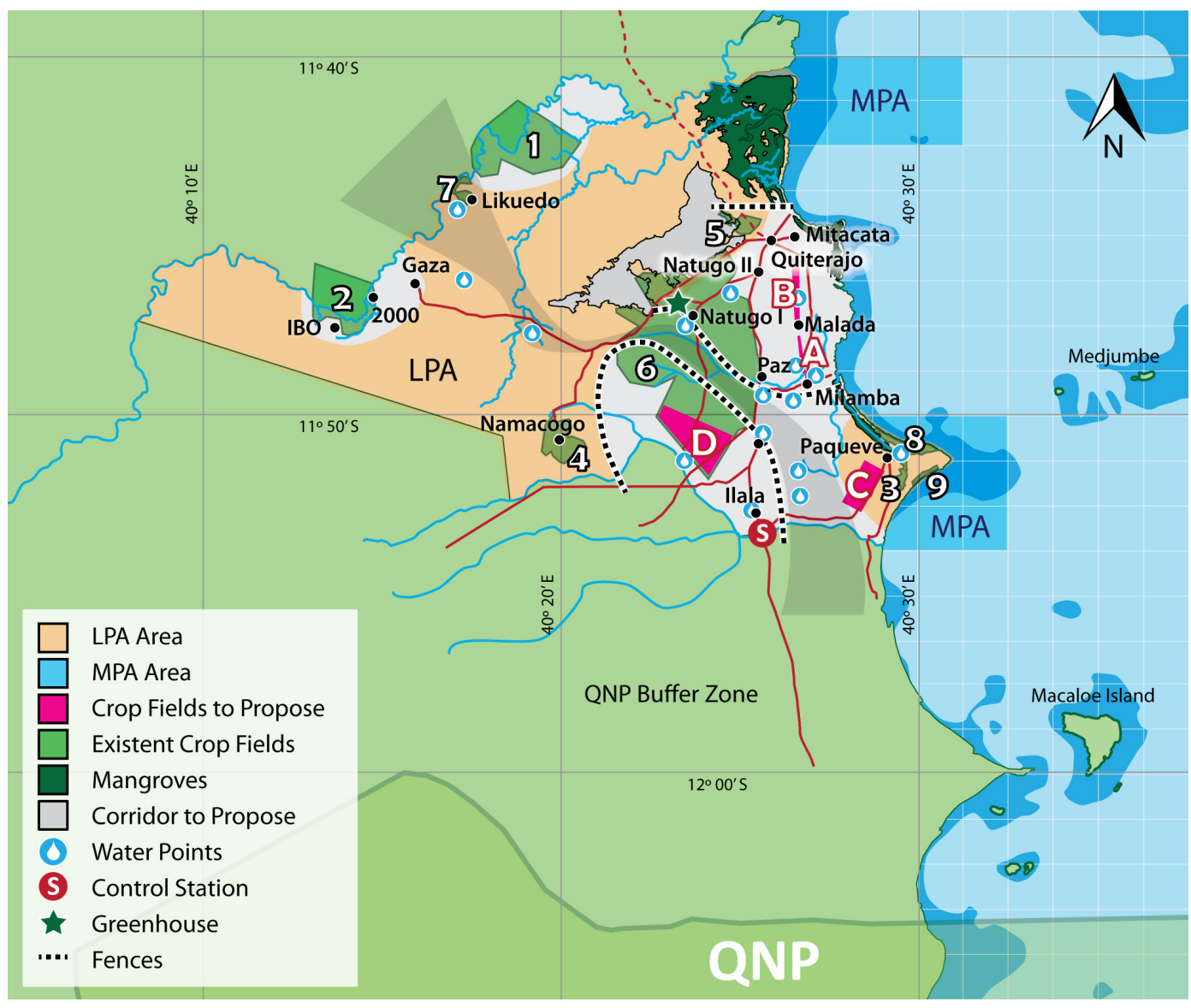

Figure 12. Case study area with identification of proposed protected areas (orange and dark blue areas). Grey-blue color is the proposed corridor at the center of the area, enclosed by fences (dashed lines). The "S" red point identifies the proposed location of the control station. Numbers correspond to green areas (farmed crop fields). Pink areas are proposed field. QNP is the "Quirimbas National Park”. 
[37], suggest that "even minor hills are considerable energy barriers for heavy animals” like elephants, which they studied. Mountaineering seems to imply for these animals overheating, risk of injury, lack of water or unsuitability of forage. Crossing and comparing Figure 11 with Figure 12 makes it evident that the protection of this corridor is crucial, because it represents a passage through long elevations. Artificial barriers (fences) can be conjugated with natural barriers to protect people and crops. Systems of detection and vigilance can be implemented and can serve as an attempted alert. Low-tech (low-cost) solutions can also be implemented particularly in remote areas such as in the rice fields of Messalo. Low-tech (also low-cost) measures like chilli pepper were used with some success (range between 37 and approximately 100\% of efficiency) in the MWA [30].

Certain areas (conditioned-use areas) can be determined as "interdict" for certain periods of time. Committees can set exceptions on a seasonal basis for resource exploitation. These areas include Mitacata, Malada and Milamba mangroves and all the beaches. The supervision of these areas could be made by "fiscais" from nearby villages.

It is important to keep specific areas (specific use areas) for free exploitation of resources. They encompass crop areas occupied by main villages like Mitacata, Natugo II, Malada, Milamba, Namaneco, Paqueve and Ilala. Rice fields in Likuedo, 2000 and Ibo should continue to be explored. Areas from $\mathrm{n}^{\circ} 1$ to 9 are crop fields which must continue to exist, with exception of area no 4. Proposed crop fields are the ones signalized with the letters A, B (palm groves), C (rice fields), and D (diverse vegetables). Area $n^{\circ} 6$ requires rehabilitation for future sustainable usage (see Section 4.2.1.1). The coastal and marine area and respective resources, situated between Messalo estuary and Paqueve-cape, could be divided subareas and consequently explored with careful supervision (see Section 4.2.1.3).

The creation of a control station is proposed near area limits, at south ("S" dot signalized near Ilala in Figure 12). This control post is intended for the recording of trade patterns and "migrations" of wild animals like elephants from the buffer zone of the QNP to the MWA. This action would allow: 1) the quantification of resources being taken from (and to) the area, and enable the identification of resource origin and destiny; 2) a complement to an accurate evaluation of the area's wealth; 3) understanding of the rate of depletion of area's natural capacity; 4) the design of a strategy to stop abuse and bad exploitation practices. A tax could be applied on goods, such as meat, noble wood, and marine resources destined to consumption outside the MWA, and on tourism activities. This is already contemplated in Mozambican law. Profit derived from this taxation method could be used to improve infrastructures such as roads and community facilities and the population's quality of life (Dec.-Lei no 10/99, 7 July, 35 article and 38 article) [38].

\subsubsection{Specific Aspects of the MP}

\section{1) Forest and Crop Management}

Results showed a high dependency on wood materials that are used for fuel and construction. Therefore a strict plan is important regarding this matter. These "pristine areas" are already inside the proposed LPA in Figure 12. Also, there is a delimitation of areas only for agriculture practices (areas $n^{\circ} 1$ to $n^{\circ} 9$ ). An additional concern was the definition of arborous species for plantation, to renew forest cover inside the MWA. What is intended is the rehabilitation of palm tree groves (section A and B), Afzelia quanzensis, Millettia stuhlmannii, Pterocarpus angolensis, Dalbergia melanoxylon, Euclea natalensis (Mulala) Olax dissitiflora (Mussiro) Strycnos spinosa (Massala), Hyphaene coriacea (Macuti-Palm tree leaves), Cocos sp. (Palm trees), cashew nut trees, Mangifera indica (Mango trees), Sclerocarya birrea subsp. caffra (Marula, Ocanho), Citrus sinensis (Orange trees), Agave sisalana (Sisal plant) dispersed in areas like $\mathrm{D}$, and $\mathrm{n}^{\circ} 1$ to $\mathrm{n}^{\circ} 9$. The improvement of forest cover would have the effect of creating new occupations, and the wood waste could be used as firelighters for cooking (thus alleviating the energy problem). Also, many of these species are used by locals on their daily tasks.

The construction of community crop fields (the machambas) away from pathways of elephants and near water supplies that are not shared with wild animals is also important to avoid and diminish HWC (see Forest and Wild Life Law [38]; Forest and Wild Life Regulation [39], Land Law [40] [41] and Land Regulation [38]; Law of the Environment [42]).

Implementation of apiculture is also advised to create new jobs (supervision and care of beehives), to increase resources (directly by collecting honey and wax, and indirectly by protecting crop fields from wild animals), and to improve bee pollenisation (an important ES).

\section{2) Fauna Management}

Elephants are not the only wild life responsible to create problems, as the answers revealed. Baboons are fre- 
quent and cause destruction of crops, albeit being more tolerated than elephants. The creation of zones only for wild life is a demanded strategy by the interviewed. However, the habitats for wild life have already been fragmented inside the MWA. Jackson et al. [43], for example, say that "land-use and zonation must be carefully planned to ensure that future patterns of human settlement avoid areas that are well used by elephants". Results show that ungulates are frequent, but are also the target of hunting. This is an indicator that the MWA provides ground for high levels of uncontrolled hunting practices, which put at risk in the short run, the existent biodiversity. An astute management of wild populations in the MWA is needed and actions against illegal hunting need to be taken. This can be supervised by the committees following taxation posted by the government to ensure animal populations' regeneration. It would also ensure that the annual hunting of animals would be done on special request to the government, providing an element of careful consideration for sustainability and a scientificbased decision [38] [39]. There is, however, a need for further surveys and multispecies monitoring programs so as to be able to identify the diversity, abundances, occurrences, seasonal distribution patterns and ecological requirements. This information would be instrumental for policy makers and law enforcement bodies.

\section{3) Fishery and Mangrove Management}

Wells et al. [44] say that the need for further MPAs is undeniably urgent, especially in Eastern Africa. Mozambique was in 2006 the country furthest away of achieving the Convention on Biodiversity MPA area target. But Mozambique and its government seems to have recognized "the economic benefits to be gained from wellmanaged marine resources, particularly in terms of coastal livelihoods and the revenue generated from tourism" [44].

Estuaries and associated mangroves are ecologically vital because they provide habitat and breeding grounds for numerous fish and crustaceous species. They also filter and retain silt brought by rivers (which could be deadly to coastal coral reefs).

Mangrove harvesting is an important source of construction materials. In a study carried in the mangroves of river Limón, older mangrove harvesters reported a decrease in local availability of the favored size of mangroves for harvesting. These observations were supported by the scientific data about the effect of harvesting. This consistency between local and scientific knowledge, suggested that harvesters have conscience of the impact of their practices in exploited mangroves [45]. Ferreira et al. [46] reported from 1995 until 2005 an increase in mangrove area, including around the Messalo estuary. These were practically undisturbed [27]. However, direct observations in 2009 and 2010 in the southern area stated that part of the mangroves was being damaged by anthropogenic action. There are still well preserved areas within the Messalo and Muenha mangroves in the North, and between Micataca and Paqueve beaches. These need to be preserved through legal enforcement and education of youngsters. Also, the creation of two small-scale marine protected areas is proposed, as seen in Figure 12: Messalo estuary-MPA and Paqueve cape-MPA. Before prohibiting fisheries in these areas there is a need to understand the opportunity costs by using a choice model, as suggested by Smith et al. [47]. The opportunities are the ones concerning "opportunities that arise in space (e.g., reserves eliminate some possible fishing grounds), in the biological domain (e.g., reserves affect the abundance of target species), and in the financial realm (e.g., reserves may alter the costs of fishing)" [47].

We focused on the preservation of the unique biodiversity of the selected areas and the preservation of the mangroves and leave the type of management decisions to the committees. Perhaps the design of a marine reserve network could be thought for the future of the region. It would be important since the area is already considered a natural reserve, it is nearby the QNP (Quirimbas National Park), whose marine area covers a coastline of $100 \mathrm{Km}$ encompassing 11 islands, and it is nearby an area which was selected as a potential transfrontier MPA. Networks of marine reserves bring benefits, not only because they are designed to meet fisheries goals focus on yield and profitability, but also because they enable "estimating ecosystem-wide effects of fishing to inform ecosystem-based fisheries management, spatially explicit stock assessments, and disentangling effects of fishing from climate change and other impacts" [48]. These networks are, probably, more effective in preserving natural and cultural heritage, and since it has a chance of increase compliance of fishermen, will yield an education of the population and younger. However, the creation of networks is a new approach, implemented only recently [48], which needs scientific supervision.

A marine turtle conservation project can be implemented. Identification and protection of nesting sites is extremely important (see Law of the Environment [42]; Water Law [49] and Law of the Sea [50] for environmental protection and land use). The nearby Vamizi Island has a program for conservation of marine turtles and exper- 
tise acquired by the Maluane that works in Vamizi [51] can be precious.

To achieve the proposed goal, Rosendo et al. [34] advise stakeholders' participation in the MPAs planning and implementation. This would help to develop a sense of ownership, to improve compliance with conservation measures [34] [52] and to address potential conflicts between users [34]. These investigations also emphasize the need for creating local-level "community fisheries councils", and recommend that marine conservation tools should be made in conjunction with resource workers [34]. It must not be forgotten that poverty is a limiting factor to conservation efforts [53].

\subsection{Proposal for Creation of Committees for Wellbeing Assessment and Management}

Management plans have been applied all over the world, with the configuration of local committees, with stakeholders and advisors, but also with local people. The involvement of the local inhabitants in a multidisciplinary approach for designing a management strategy is advised by specialists like Paterson [10], Pollnac [11] and Pomeroy et al. [54]. Following these specialists' recommendations a committee was configured to manage the MWA, shown in Figure 13. It is proposed that local decision groups (committees) lead the wellbeing assessment, having this study as basis.

It is recognized, however, that the implementation of successful management plans is extremely difficult [1] [55] [56]. Several studies reinforce that management plans are more successful when they simultaneously create incentives for local communities [56], or when they involve the population during plan preparation [34]. Fraser et al. [6] emphasize the need for integration of local knowledge, scientific research and policy support, in a bottom-up perspective, in the preparation of a list of indicators to project a MP. The idea of the creation of man-

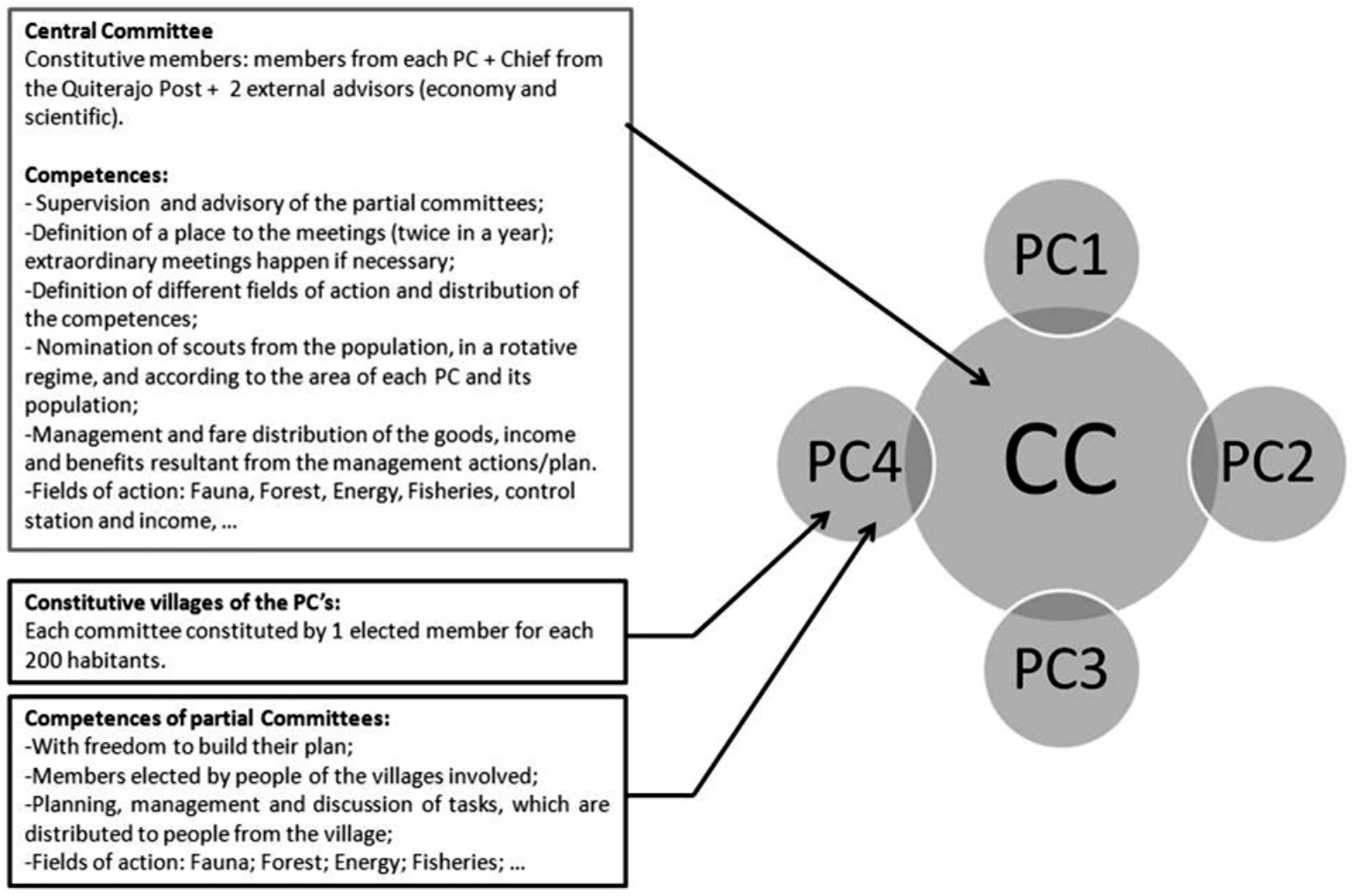

Figure 13. Structure for the committees. The central committee (CC) may be composed by 7/8 members: 4 members (or more) from partial committees (PC) and 2/3 more invited members (scientific supervisor, member of one NGO operating in the area, etc.). Each PC may be composed by one village chief (political, traditional; both if they exist), a teacher, one traditional healer, the religious leader and one citizen member elected for each 200 inhabitants. The proposal of distribution of villages by committees is the following: PC Quiterajo-Mitacata (reunites villages of Quiterajo, Mitacata, Natugo I, Natugo II, Likuedo, Gaza, Ibo and village “2000”); PC Ilala-Namaneco (reunites villages of Ilala and Namaneco); PC Milamba (reunites villages of Milamba, Paz, Unidade and Malada); PC Paqueve (reunites villages of Paqueve and Mwera). 
agement committees is also supported by Mozambican Law [38]. Hence, following these perspectives we suggest the creation of one Central Committee (CC) with multidimensional knowledge [57], and four Partial Committees (PC) for the area (Figure 13).

The roles of the CC can include, among others, ensuring the participation of local communities, articulating government strategies in sustainable exploitation of natural resources, supervising PC administration, administrating generated income, managing revenue application into community facilities, searching for relevant external assistance and funding to establish and maintain the management regime, spreading awareness on and applying education programs and, finally, creating community support programs. PCs may decide on field practices, and therefore an argument can be made on giving them the control to adapt CC measures. They may organize food provision, reinforcement of intercommunity relations, and conflict mitigation (among resource users, among animals and humans).

\section{Conclusions}

There is a considerable amount of methods and recommendations that need to be taken in consideration before designing an ES management plan. Each case is different as regards the community, their culture, aspirations and expectations, their views and commitment levels towards wildlife and natural resources. The MWA management plan and the creation of committees represent a strategy. The DQ is a tool which can easily be applied by these committees to complete the human wellbeing assessment, and it can be applied for the same purposes in other areas of MZ or eastern Africa, and similar coastal areas of the world. There are, however, problems to debate and deal with. The attraction of further numbers of people to the MWA can increase pressure on natural resources.

Overall, following the work presented in this study, we hope to achieve the emergence of ecological awareness and change of values that promote biodiversity, as a first step towards a sustainable economy for the MWA, and for other areas of Eastern/Central Africa.

\section{Acknowledgements}

The authors would like to thank the Maluane scouts, Rachid Abudala (Major Dade), and Dusan Misic (Zemun Agro Industrial—www.pembazemun.com/aboutus.html) for their help during field work. We address our gratitude to Sérgio Cardoso due to the precious support given to the informatic and digital artwork. We are also grateful to several institutions, iTC-Cabo Delgado, Maluane and AFPR which have contributed for the project "Área de Conservação do Messalo-Gestão dos Recursos Naturais".

Views expressed in this paper are those of the authors. They do not represent the views of the financial sponsors of this work or the authors' institution.

\section{References}

[1] MEA (Millennium Ecosystem Assessment) (2005) Ecosystems and Human Well-Being: Biodiversity Synthesis. World Resources Institute, Washington DC.

[2] Díaz, S., Fargione, J., Chapin III, F.S. and Tilman, D. (2006) Biodiversity Loss Threatens Human Well-Being. PLoS Biology (Public Library of Science), 4, 1300-1305. http://dx.doi.org/10.1371/journal.pbio.0040277

[3] Palmer, M.A. (2010) Water Resources: Beyond Infrastructures. Nature, 467, 534-535. http://dx.doi.org/10.1038/467534a

[4] Costanza, R., d’Arge, R., Groot, R., Farber, S., Grasso, M., Hannon, B., Limburg, K., Naeem, S., O’Neill, R.V., Paruelo, J., Raskin, R.G., Sutton, P. and van den Belt, M. (1997) The Value of the World's Ecosystem Services and Natural Capital. Nature, 387, 253-260. http://dx.doi.org/10.1038/387253a0

[5] Rands, M.R.W., Adams, W.M., Bennun, L., Butchart, S.H.M., Clements, A., Coomes, D., Entwistle, A., Hodge, I., Kapos, V., Scharlemann, J.P.W., Sutherland, W.J. and Vira, B. (2010) Biodiversity Conservation: Challenges Beyond 2010. Science, 329, 1298-1303. http://dx.doi.org/10.1126/science.1189138

[6] Fraser, E.D.G., Dougill, A.J., Mabee, W.E., Reed, M. and McAlpine, P. (2006) Bottom up and Top down: Analysis of Participatory Processes for Sustainability Indicator Identification as a Pathway to Community Empowerment and Sustainable Environmental Management. Journal of Environmental Management, 78, 114-127. http://dx.doi.org/10.1016/j.jenvman.2005.04.009

[7] Garnier, J., Dunham, K.M., Robertson, E.F. and Murphree, M. (1999) An Ecological and Sociological Survey in Cabo 
Delgado Province, Northern Mozambique. Survey and Recommendations for the Conservation of Terrestrial and Marine Resources and for Community Involvement. Cabo Delgado Biodiversity and Tourism Project. Cabo Delgado Investments Limited, Paris.

[8] Garnier, J. (2003) Cabo Delgado: Biodiversity and Tourism Project-Management Plan (2003-2006). Maluane, Cabo Delgado Biodiversity and Tourism, Pemba.

[9] Bradshaw, G.A. and Bekoff, M. (2001) Ecology and Social Responsibility: The Re-Embodiment of Science. Trends in Ecology \& Evolution, 16, 460-465. http://dx.doi.org/10.1016/S0169-5347(01)02204-2

[10] Paterson, B., Isaacs, M., Hara, M., Jarre, A. and Moloney, C.L. (2010) Transdisciplinary Co-Operation for an Ecosystem Approach to Fisheries: A Case Study from the South African Sardine Fishery. Marine Policy, 34, 782-794. http://dx.doi.org/10.1016/j.marpol.2010.01.019

[11] Pollnac, R., Christie, P., Cinner, J.E., Dalton, T., Daw, T.M., Forrester, G.E., Graham, N.A.J. and McClanahan, T.R. (2010) Marine Reserves as Linked Social-Ecological Systems. Proceedings of the National Academy of Sciences of the United States of America, 107, 18262-18265. http://dx.doi.org/10.1073/pnas.0908266107

[12] RM (República de Moçambique) (2002) Decreto N 14/2002 de 6 de Junho. Parque Nacional das Quirimbas-Criação: Mapa e coordenadas. Imprensa Nacional de Moçambique, Boletim da República, I Série-N²2, 194-(28-29).

[13] Moreira, C.D. (1994) Planeamento e Estratégias de Investigação Social. Instituto Superior de Ciências Sociais e Políticas, Lisboa.

[14] Pinto, R.R. (2009) Introdução à análise de dados com recurso ao SPSS. Edições Sílabo, Lda., Lisboa.

[15] Bardin, L. (2004) Análise de Conteúdo. Edições 70, Lisboa.

[16] Pereira, A. (2006) Guia Prático de Utilização do SPSS—Análise de Dados para Ciências Sociais e Psicologia. 6th Edition, Edições Sílabo, Lda., Lisboa.

[17] DSA (Direcção dos Serviços de Agrimensura) (1960) Atlas de Moçambique. Empresa Moderna, Lda., Lourenço Marques.

[18] IH (Instituto Hidrográfico) (1965) Canal de Moçambique—Carta Hidrográfica da Foz do Rovuma ao Ibo (1:250 000). Instituto Hidrográfico, Lisboa.

[19] Richmond, M.D., Ed. (2002) A Fild Guide to the Seashores of Eastern Africa and the Western Indian Ocean Islands. Sida/SAREC-UDSM.

[20] Sousa, A.G. (1966) Dendrologia de Moçambique, Estudo Geral, Vol. I, Série: Memórias, No 1. Instituto de Investigação Agronómica de Moçambique-Centro de Documentação Agrária, Imprensa Nacional de Moçambique, Lourenço Marques.

[21] Azevedo, A.L. (1955) Clima. Estudo de Alguns Factores Climáticos. In: Esboço do Reconhecimento EcológicoAgricola de Moçambique, Imprensa Nacional de Moçambique, Lourenço Marques, 147-243.

[22] De Martonne, E. (1925) Traité de Geographie Physique. A. Colin, Paris.

[23] White, F. (1983) The Vegetation of Africa, a Descriptive Memoir to Accompany the UNESCO/AETFAT/UNSO Vegetation Map of Africa (3 Plates, Northwestern Africa, Northeastern Africa, and Southern Africa, 1:5,000,000. UNESCO, Paris.

[24] Wild, H. and Grandvaux Barbosa, L.A. (1967) Vegetation Map (1:2,500,000 in Colour) of the Flora Zambesiaca Area, Descriptive Memoir. Supplement to Flora Zambesiaca, M.O. Collins Ltd., Salisbury.

[25] Timberlake, J.G. (2009) Coastal Dry Forest of Cabo Delgado. In: Pascal, O., Compiler, Mozambique—Madagascar Expeditions 2008-2010. Mozambique 2008: Reconnaissance of Coastal Forest in Cabo Delgado, 22 November-13 December 2008, Expedition Report, Pro-Natura International \& Muséum National d'Histoire naturelle, Paris, 16-29.

[26] Timberlake, J.R., Goyder, D.J., Crawford, F. and Pascal, O. (2011) Coastal Dry Forests in Cabo Delgado Province, Northern Mozambique-Botany \& Vegetation. In: Pascal, O., Compiler, The Coastal Forests of Northern Mozambique, 2008-2009 Expeditions, “Our Planet Reviewed”, Programme Report No 1, Pro-Natura International \& Muséum national d'Histoire naturelle, Paris, 11-113.

[27] Wacher, T. and Garnier, J. (2005) Habitat Mapping \& Land Use Zonation Study-Messalo Wilderness Area. Maluane, Cabo Delgado Biodiversity and Tourism Project, Pemba and the Zoological Society of London, Conservation Programmes, London.

[28] Bandeira, S. and Nacamo, E. (2007) Preliminary Vegetation Survey at Quiterajo, Cabo Delgado. Maluane, Cabo Delgado Biodiversity and Tourism Project, Pemba and UEM, Maputo.

[29] Wacher, T. and Garnier, J. (2003) Wildlife Survey and Training Programme-Messalo River Floodplain and Woodlands. Maluane, Cabo Delgado Biodiversity and Tourism Project, Pemba and the Zoological Society of London, Conservation Programmes, London.

[30] Garnier, J. (2006) Human/Elephant Conflict in the Messalo Wilderness Area. Report of Management Activities \& 
Recommendations. Maluane, Cabo Delgado Biodiversity and Tourism Project, Pemba and the Zoological Society of London, Conservation Programmes, London.

[31] Ntumi, C.P., Ferreira, S.M. and van Aarde, R.J. (2009) A Review of Historical Trends in the Distribution and Abundance of Elephants Loxodonta africana in Mozambique. Fauna \& Flora International, Oryx, 43, 568-579. http://dx.doi.org/10.1017/S0030605309990482

[32] MAE (Ministério da Administração Estatal) (2005) Perfil do Distrito de Macomia-Província de Cabo Delgado. Direç̧ão Nacional da Administração Local (Coord.), Série Perfis Distritais de Moçambique, Maputo.

[33] Mabunda, R. (2005) Livelihoods: An Analysis and Proposal to Reconcile Conservation and Development in the Buffer Zone of the Quirimbas National Park, Maputo.

[34] Rosendo, S., Brown, K., Joubert, A., Jiddawi, N. and Mechisso, M. (2011) A Clash of Values and Approaches: A Case Study of Marine Protected Area Planning in Mozambique. Ocean \& Coastal Management, 54, 55-65. http://dx.doi.org/10.1016/j.ocecoaman.2010.10.009

[35] Hoare, R. (2012) Lessons from 15 Years of Human-Elephant Conflict Mitigation: Management Considerations Involving Biological, Physical and Governance Issues in Africa. Pachyderm N51, 60-74.

[36] Douglas-Hamilton, I., Krink, T. and Vollrath, F. (2005) Movements and Corridors of African Elephants in Relation to Protected Areas. Naturwissenschaften, 92, 158-163. http://dx.doi.org/10.1007/s00114-004-0606-9

[37] Wall, J., Douglas-Hamilton, I. and Vollrath, F. (2006) Elephants Avoid Costly Mountaineering. Current Biology, 16, R527-R529. http://dx.doi.org/10.1016/j.cub.2006.06.049

[38] RM (República de Moçambique) (1999) Lei N 10/99 de 7 de Julho. Princípios e normas sobre protecção, conservação e utilização sustentável dos recursos florestais e faunísticos. Imprensa Nacional de Moçambique, Boletim da República, I Série- $\mathrm{N}^{\circ}$ 27, 4 Suplemento, 126-(31-39).

[39] RM (República de Moçambique) (2002) Decreto N 12/2002 de 6 de Junho. Regulamento da Lei de Florestas e Fauna Bravia. Imprensa Nacional de Moçambique, Boletim da República, I Série-N²2, 194-(3-27).

[40] RM (República de Moçambique) (1997) Decreto N 19/1997 de 1 de Outubro. Lei da Terra. Imprensa Nacional de Moçambique, Boletim da República, I Série- $\mathrm{N}^{\circ}$ 40, 200-(15-19).

[41] RM (República de Moçambique) (1998) Decreto N 66/1998 de 8 de Dezembro. Regulamento da Lei da Terra. Imprensa Nacional de Moçambique, Boletim da República, I Série-N²48, 225-(33-40).

[42] RM (República de Moçambique) (1997) Decreto N²0/1997 de 1 de Outubro. Lei do Ambiente. Imprensa Nacional de Moçambique, Boletim da República, I Série-N²40, 200-(19-24).

[43] Jackson, T.P., Mosojane, S., Ferreira, S.M. and van Aarde, R.J. (2008) Solutions for Elephant Loxodonta africana Crop Raiding in Northern Botswana: Moving away from Symptomatic Approaches. Fauna \& Flora International, Oryx, 42, 83-91. http://dx.doi.org/10.1017/S0030605308001117

[44] Wells, S., Burgess, N. and Ngusaru, A. (2007) Towards the 2012 Marine Protected Area Targets in Eastern Africa. Ocean \& Coastal Management, 50, 67-83. http://dx.doi.org/10.1016/j.ocecoaman.2006.08.012

[45] López-Hoffman, L., Monroe, I.E., Narváez, E., Martínez-Ramos, M. and Ackerly, D.D. (2006) Sustainability of Mangrove Harvesting: How Do Harvesters’ Perceptions Differ from Ecological Analysis? Ecology and Society, 11, 14. [online] http://www.ecologyandsociety.org/vol11/iss2/art14/

[46] Ferreira, M.A., Andrade, F., Bandeira, S.O., Cardoso, P., Mendes, R.N. and Paula, J. (2009) Analysis of Cover Change (1995-2005) of Tanzania/Mozambique Trans-Boundary Mangroves Using Landsat Imagery. Aquatic Conservation: Marine and Freshwater Ecosystems, 19, S38-S45. http://dx.doi.org/10.1002/aqc.1042

[47] Smith, M.D., Lynham, J., Sanchirico, J.N. and Wilson, J.A. (2010) Political Economy of Marine Reserves: Understanding the Role of Opportunity Costs. Proceedings of the National Academy of Sciences of the United States of America, 107, 18300-18305. http://dx.doi.org/10.1073/pnas.0907365107

[48] Gaines, S.D., White, C., Carr, M.H. and Palumbi, S.R. (2010) Designing Marine Reserve Networks for both Conservation and Fisheries Management. Proceedings of the National Academy of Sciences of the United States of America, 107, 18286-18293. http://dx.doi.org/10.1073/pnas.0906473107

[49] RM (República de Moçambique) (1991) Decreto N²0/1997 de 3 de Agosto. Lei de Águas. Imprensa Nacional de Moçambique, Boletim da República, I Série-N³1, 2 Suplemento, 214-(12-22).

[50] RM (República de Moçambique) (1996) Decreto $N^{\circ}$ 4/1996 de 4 de Janeiro. Lei do Mar. Imprensa Nacional de Moçambique, Boletim da República, I Série- $\mathrm{N}^{\circ}$ 1, 4-(10-15).

[51] Anastácio, R., Santos, C., Lopes, C., Moreira, H., Souto, L., Ferrão, J., Garnier, J. and Pereira, M.J. (2014) Reproductive Biology and Genetic Diversity of the Green Turtles (Chelonia mydas) in Vamizi Island, Mozambique. Springer- Plus, 3, 540. http://dx.doi.org/10.1186/2193-1801-3-540

[52] McClanahan, T.R., Marnane, M.J., Cinner, J.E. and Kiene, W.E. (2006) A Comparison of Marine Protected Areas and 
Alternative Approaches to Coral-Reef Management. Current Biology, 16, 1408-1413. http://dx.doi.org/10.1016/j.cub.2006.05.062

[53] Tobey, J. and Torell, E. (2006) Coastal Poverty and MPA Management in Mainland Tanzania and Zanzibar. Ocean \& Coastal Management, 49, 834-854. http://dx.doi.org/10.1016/j.ocecoaman.2006.08.002

[54] Pomeroy, R.S., Watson, L.M., Parks, J.E. and Cid, G.A. (2005) How Is Your MPA Doing? A Methodology for Evaluating the Management Effectiveness of Marine Protected Areas. Ocean \& Coastal Management, 48, 485-502. http://dx.doi.org/10.1016/j.ocecoaman.2005.05.004

[55] Oldekop, J.A., Bebbington, A.J., Brockington, D. and Preziosi, R.F. (2010) Understanding the Lessons and Limitations of Conservation and Development. Conservation Biology, 24, 461-469. http://dx.doi.org/10.1111/j.1523-1739.2010.01456.x

[56] Dahlberg, A.C. and Burlando, C. (2009) Addressing Trade-Offs: Experiences from Conservation and Development Initiatives in the Mkuze Wetlands, South Africa. Ecology and Society, 14, 37. [Online] http://www.ecologyandsociety.org/vol14/iss2/art37

[57] Laumonier, Y., Bourgeois, R. and Pfund, J.L. (2008) Accounting for the Ecological Dimension in Participatory Research and Development: Lessons Learned from Indonesia and Madagascar. Ecology and Society, 13, 15. [Online] http://www.ecologyandsociety.org/vol13/iss1/art15/ 
Scientific Research Publishing (SCIRP) is one of the largest Open Access journal publishers. It is currently publishing more than 200 open access, online, peer-reviewed journals covering a wide range of academic disciplines. SCIRP serves the worldwide academic communities and contributes to the progress and application of science with its publication.

Other selected journals from SCIRP are listed as below. Submit your manuscript to us via either submit@scirp.org or Online Submission Portal.
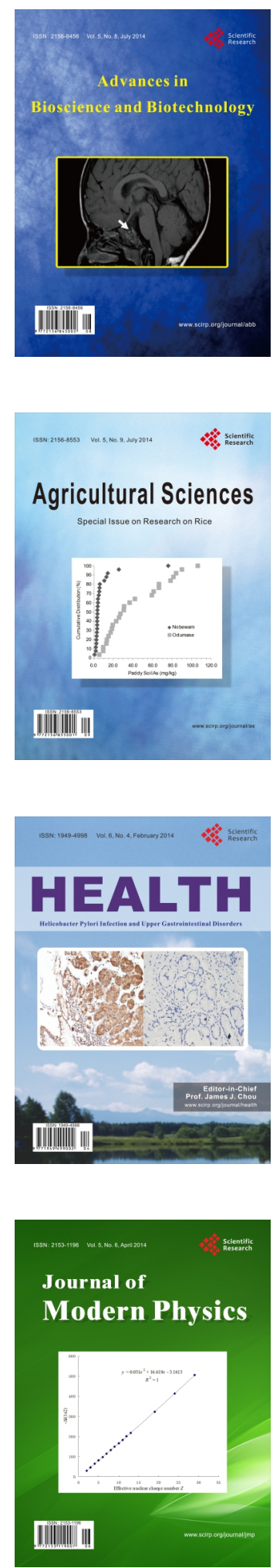
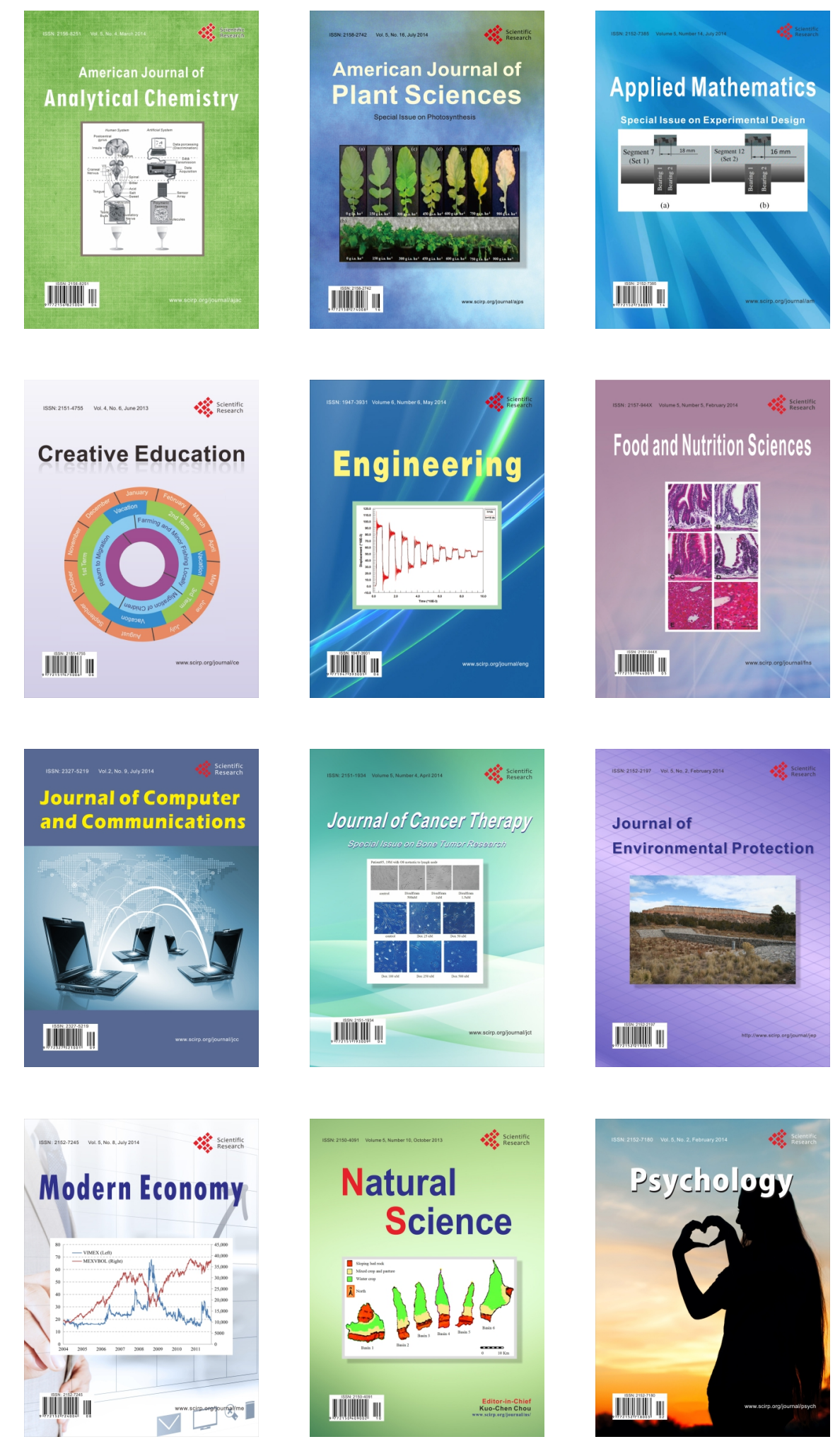